This item was submitted to Loughborough's Research Repository by the author.

Items in Figshare are protected by copyright, with all rights reserved, unless otherwise indicated.

\title{
Microparticles for cell encapsulation and colonic delivery produced by membrane emulsification
}

PLEASE CITE THE PUBLISHED VERSION

http://dx.doi.org/10.1016/j.memsci.2016.11.058

PUBLISHER

(C) Elsevier

VERSION

AM (Accepted Manuscript)

\section{PUBLISHER STATEMENT}

This work is made available according to the conditions of the Creative Commons Attribution-NonCommercialNoDerivatives 4.0 International (CC BY-NC-ND 4.0) licence. Full details of this licence are available at: https://creativecommons.org/licenses/by-nc-nd/4.0/

\section{LICENCE}

CC BY-NC-ND 4.0

\section{REPOSITORY RECORD}

Morelli, Serena, Richard Holdich, and Marijana Dragosavac. 2016. "Microparticles for Cell Encapsulation and Colonic Delivery Produced by Membrane Emulsification". Loughborough University.

https://hdl.handle.net/2134/23463. 


\section{Author's Accepted Manuscript}

$\begin{array}{llr}\text { MICROPARTICLES } & \text { FOR } & \text { CELL } \\ \text { ENCAPSULATION } & \text { AND } & \text { COLONIC } \\ \text { DELIVERY PRODUCED } & \text { BY } & \text { MEMBRANE } \\ \text { EMULSIFICATION } & & \end{array}$

S. Morelli, R.G. Holdich, M.M. Dragosavac

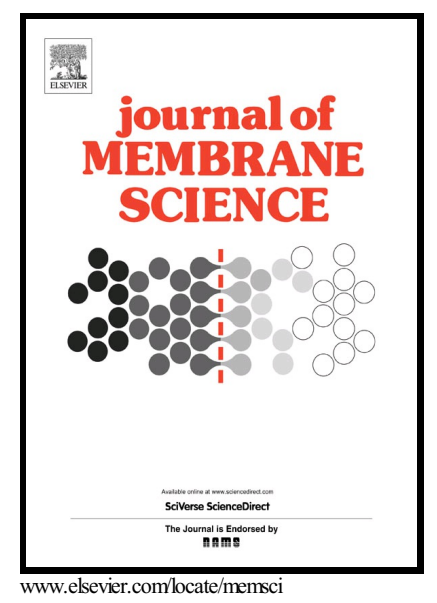

PII: $\quad$ S0376-7388(16)30746-3

DOI: $\quad$ http://dx.doi.org/10.1016/j.memsci.2016.11.058

Reference: MEMSCI14898

To appear in: Journal of Membrane Science

Received date: 21 June 2016

Revised date: 15 November 2016

Accepted date: 16 November 2016

Cite this article as: S. Morelli, R.G. Holdich and M.M. Dragosavac MICROPARTICLES FOR CELL ENCAPSULATION AND COLONIC DELIVERY PRODUCED BY MEMBRANE EMULSIFICATION, Journal c Membrane Science, http://dx.doi.org/10.1016/j.memsci.2016.11.058

This is a PDF file of an unedited manuscript that has been accepted fo publication. As a service to our customers we are providing this early version o the manuscript. The manuscript will undergo copyediting, typesetting, an review of the resulting galley proof before it is published in its final citable form Please note that during the production process errors may be discovered whic could affect the content, and all legal disclaimers that apply to the journal pertain 


\title{
MICROPARTICLES FOR CELL ENCAPSULATION AND COLONIC DELIVERY PRODUCED BY MEMBRANE EMULSIFICATION
}

\author{
Morelli S., Holdich R.G., Dragosavac M.M* \\ Department of Chemical Engineering, Loughborough University, Leicestershire LE11 3TU, UK \\ *Corresponding Author: Chemical Engineering Department, Loughborough University, Loughborough, LE113TU, \\ UK, Phone: +44 (0) 1509222 501, Email: M.Dragosavac@lboro.ac.uk
}

\begin{abstract}
Membrane Emulsification was used to encapsulate yeast cells and form microparticles. W/O emulsions were produced using a Dispersion Cell; the aqueous phase consisted of gelatin/chitosan, or pure gelatin solution, containing yeast cells, the continuous phase was 2 wt. $\%$ of SPAN 80 in kerosene. Varying the dispersed phase flux (from 70 to $350 \mathrm{~L} \mathrm{~h}^{-1} \mathrm{~m}^{-2}$ ) and the shear stress (from 17 to $1 \mathrm{~Pa}$ ) applied on the membrane surface droplet sizes of between 60 to $340 \mu \mathrm{m}$ were produced, with a coefficient of variation of $17 \%$ under the best operating conditions. The liquid drops were loaded with increasing amount of yeast $\left(3.14 \times 10^{7}\right.$ to $3.14 \mathrm{x}$ $10^{8}$ cells $/ \mathrm{mL}$ ). The stability and uniformity of the emulsions was independent of the cell concentration. PTFE coated hydrophobic membrane produced smaller W/O drops compared to FAS coated membranes. The liquid polymeric droplets were solidified in solid particles using thermal gelation and/or ionic crosslinking, obtaining yeast encapsulated particles sized $\sim 100 \mu \mathrm{m}$. The $\mathrm{pH}$ sensitive polymer, Eudragit S100, was used as a coating to create gastro resistant particles suitable for intestinal-colonic targeted release. Viability of the released yeast cells was demonstrated using fluorescence probes and checking cell glucose metabolism with time.
\end{abstract}

\section{Abbreviations}

W/O emulsion, water in oil emulsion; G, gelatin; CS, chitosan; SPAN 80, Sorbitan monooleate 80; CV, Coefficient of Variation; $\mathrm{D}_{\mathrm{av}}$, median average drop diameter, SHMP, sodium hexametaphosphate; Tween 20, Polyethylene glycol sorbitan monolaurate; PTFE, Polytetrafluoroethylene; FAS, (Fluoro Alkyl Silane); ME, membrane emulsification; SPG membrane, Shirasu-porousglass membrane.

\section{Keywords}


Dispersion Cell Membrane Emulsification, cell encapsulation, W/O emulsions, Eudragit S100 coating, intestine-colon targeted release 


\section{Introduction}

The encapsulation of living microorganisms as well as cells, for the purpose of a therapy, is a relatively recent and promising technique relevant to a broad range of sectors, from medicine to the food industry. The technology of cell encapsulation is applied as a method to deliver therapeutics in a desired rate and for longer period, by controlled or triggered release of an active ingredient. Unlike the encapsulation of proteins, encapsulated cells can be used to synthetize the therapeutic product, giving a physiological concentration of an active ingredient with time[1]. Furthermore, due to the in-situ manufacture of the active ingredient the risk of a toxic release of a therapeutic is avoided in the case of unexpected breaking of the encapsulated particles[1]. The immobilization of cells in particles is widely discussed in tissue engineering; the possibility to encapsulate non-human cells reduces the host's immune system response, facilitating transplantation as an alternative to the limited donor tissues available[1]. The technique of cell encapsulation is being used for the production of "Bio artificial Pancreas"[2], immunobarrier for islet cells transplantation[2-4], and the encapsulation of stem cells $[5,6]$. Encapsulation of living cells was also suggested for the production of chemicals such as alcohol, organic acids, steroids, antibiotics, vaccines[7]. In the brewing industry immobilized cells (yeast cells) are used to increase the productivity in fermentation and maturation[8,9]. Immobilized yeast are also reported for wine and cider production[2,10], giving an overall costs reduction[10]. The increase in productivity is a consequence of the continuous operations practicable with encapsulated cells[11], increased cell density, facilitated cell recovery and re-use, enhanced yeast stability, increased yeast tolerance to ethanol and acetic acid, increased fermentation time, protection from harsh environments, reduced contamination[2,11]. Encapsulated yeast in alginate and carregeean beads are also reported as biocatalysts in organic solvents for complex reduction reactions[12]. There are reports[13] of the use of immobilized yeast in a polyacrylamide hydrogel for the production of L-phenylacetyl carbinol; an intermediate in the synthesis of L-ephedrine (used as an antiasthmatic and decongestant). Yeast cells were also encapsulated in colloidosomes, preserving their metabolic activity[14]. S. Graff et al. work[15] reported that the yeast species S. Boulardii has proven probiotic activity, and is being used for the treatment of enteritis, colitis and as antidiarrhoea agent. S. Boulardii is sensitive to the acidic environment in the stomach and by encapsulating in alginate beads it is a possible to protect the cells and increase the intestinal delivery. To achieve a targeted drug release in the intestinal area, it is also possible to coat the microparti- 
cles using a proprietary coating material, resistant to the acidic stomach environment but which is soluble in basic-neutral conditions: Eudragit S100[16]. The pH dependent polymer Eudragit S100 is used in drug delivery for the production of colonic delivery systems[17]; it is an anionic copolymer based on methacrylic acid and methyl methacrylate which dissolves above pH 7. Eudragit coated microparticles were produced for the colonic release of therapeutics[16,18] or proteins[19], but it has not yet been applied for the coating of encapsulated cells. A variety of materials have been tested for the encapsulation of living cells; alginate[4,6,8,12,15,20-23] is the most common and versatile, chitosan[9,23], gelatin[22,24], cellulose[23,25], agarose[23,26], dextran[1], carrageenan[9,12,27], poly(lactide-co-glycolide) (PLGA)[1,23], Poly (Ethylene Glycol)[23,28] all have been used individually, and in blends[1,27]. Chitosan is a proven biocompatible natural polymer produced from natural sources (crustacean shells, fungi, and insects), which has been widely used for cell encapsulation and other pharmaceutical purposes[23,29]. Its popularity is due to the possibility to prepare the hydrogel under relatively mild gelation conditions[30] using negatively charged ions and molecules, such as tripolyphosphate[31] or hexametaphosphate[32]. Chitosan is particularly advantageous as a material for the encapsulation of delicate compounds such as cells. In some cases the presence of positive charges of chitosan can interfere with the function of some cells and ionically crosslinked chitosan is not as mechanically stable as polymerized materials. To improve the mechanical and biological proprieties, chitosan is often used in association with other polymers, such as gelatin[23,33]. Gelatin presents many advantages as a material for cell encapsulation: it is non-toxic and biodegradable, and it is extensively used in the pharmaceutical industry as an excipient[33]. A further advantage of gelatin is its ability to form hydrogels by thermal gelation, by decreasing the temperature below $20^{\circ} \mathrm{C}$, and that it will melt again at body temperature $\left(\sim 37^{\circ} \mathrm{C}\right)[34]$. In other work, glutaraldehyde crosslinked chitosan/gelatin microparticles were produced and tested, providing reported good biocompatibility and cytotoxicity of the two materials[33].

Associated with the right material, the choice of the right encapsulation technique is fundamental for the success of an encapsulation process. Many techniques for cell encapsulation have been reported, including interfacial polymerization[12] and solvent evaporation[7], sol-gel process[35], photolithography[28], ionic crosslinking[27]. In some cases, these techniques involve the prior formation of polymeric droplets in an oil-organic phase. The use of: organic solvents; harsh environments; high shear stress and high temperature, are all disadvantages for the encap- 
sulation of delicate organic material such as cells. Thus, the process of particle formation has to be carefully selected. Droplet production can essentially be classified in to two types: single or series drop formation techniques (extrusion- laminar jet break-up[15]; microfluidic devices[21]), and bulk or parallel techniques (stirring[7,36]; Membrane Emulsification (ME)[20])). To-date, Song et al.[20] is the only work reported for the encapsulation of cells using an SPG membrane. In that work there were no details of cell density used. ME is not an obvious choice for cell encapsulation: the microfilters used would be expected to filter out the suspended cells, rather than allow the passage of the cells from one side of the membrane to the other. ME being a method to produce emulsions that consists of injecting the dispersed phase for the emulsion through the pores of a membrane into another phase[37]. The detachment of the drops is produced by applying a shear over the membrane surface[38]. The method applies in a variety of emulsion types: oil-in-water (O/W), water-in-oil (W/O) and double or multiple emulsions[39]. The method overcomes some of the disadvantages typical for other techniques of emulsions production (high pressure homogenization, rotor-stator systems) including poor droplet size uniformity, problematic scale-up, application of high mechanical forces (high shear)[40]. With ME it is possible to produce reasonably uniform emulsions with the desired droplet size by modifying the operating parameters of the process. It uses low shear conditions and requires low energy input[38,41]. ME is easier to scale up and has a higher productivity compared to the other "drop-by-drop" methods of emulsion production (microchannel and microfluidic devices)[42]. All these characteristics make ME particularly advantageous for the encapsulation of shear sensitive, temperature sensitive and delicate compounds such as drugs, proteins and cells, provided that it can be shown that the membrane used for the emulsification does not filter out the cells to be encapsulated. The tortuous pore channel microfilters (porous glass and ceramic) are most likely to deposit particulate matter (i.e. cells) within the membrane matrix over a period of time.

An alternative ME system, used in this work, employs a flat disk membrane with straight rectilinear[29] pores in a regular array[37]. The lack of a tortuous pore channel minimizes membrane fouling, or cell filtration, during the process of encapsulation. In this work the Dispersion Cell Membrane Emulsification device[29,37,40,42] is used for the production of W/O emulsions containing yeast cells using micro-sieve type metal membranes made hydrophobic by a process of surface coating. The performance of hydrophobic membranes coated with different methods (PTFE and FAS fluorinated compounds) is shown. Compared to SPG and ceramic membranes, 
the micro-sieve metal membranes can be cleaned more easily and tolerate higher fluxes[43]. The micro-sieve metal membranes are appropriate for cell encapsulation, as conditions that may cause membrane blockage, or cell filtration, can be avoided. Microparticles made of blended chitosan with gelatin, or pure gelatin, were produced for the encapsulation of yeast and the simulated release of yeast into the intestine-colon was investigated. To prevent the premature release of the yeast in the stomach, an acid resistant coating agent (Eudragit S100) was used.

\section{Experimental}

\subsection{Materials}

The oil phase (O) of the W/O emulsion was 2 wt.\% Sorbitan monooleate, SPAN 80 (Sigma Aldrich, UK) in low odor kerosene (Sigma Aldrich, UK). The emulsion water phase (W) was composed of blended chitosan (CS) (MW 50.000-190.000 g/mol Sigma Aldrich, UK) and gelatin (G) from porcine skin, gel strength 300, Type A (Sigma Aldrich, UK), or gelatin in deionized water without CS. Chitosan and gelatin solutions were prepared separately and mixed together afterwards; chitosan is soluble in acetic acid solution (Fisher Scientific, UK) with a pH below 6[29]. CS was dissolved in warm $\left(50-60^{\circ} \mathrm{C}\right) 2$ wt.\% glacial acetic acid in water. Gelatin solution was prepared by dissolving gelatin in warm water $\left(50-60^{\circ} \mathrm{C}\right)$. For the preparation of the blend, the two polymeric solutions were mixed together in an appropriate ratio and stirred for at least 2 hours, at $40^{\circ} \mathrm{C}$ to avoid the gelatin coagulation. Where appropriate, the dispersed phase contained Baker's yeast cells (Saccharomyces cerevisiae) purchased from a supermarket (Sainsbury's Fast Action Dried Bread Yeast). The median size of the yeast cells was $4 \mu \mathrm{m}$, determined using the Javabased image processing package ImageJ on microphotographs taken using an optical/fluorescent microscope (GXML3201, GX microscope) with an attached Retiga 6000 colour camera. To make a yeast suspension $3.5 \mathrm{~g}$ of the dried yeast powder was added to $200 \mathrm{~mL}$ of ultrapure water and stirred for at least 10 minutes, after complete dissolution the suspension was centrifuged at 1200 RPM for 3 minutes. The supernatant was discarded and the washing procedure was repeated 3 times. The final volume of water removed was $175 \mathrm{~mL}$. Considering the yeast cell as having a spherical shape with an average diameter of $4 \mu \mathrm{m}$ and a dry mass density of $1.33 \mathrm{~g} \mathrm{~mL}^{-1}$, the calculated maximum concentration of yeast in the suspension was $3.14 \times 10^{9}$ cells $\mathrm{mL}^{-1}$. The initial cell suspension was subsequently diluted for use by factors of 10 and 100, giving cell concentrations of $3.14 \times 10^{7}$ and $3.14 \times 10^{8}$ cells $\mathrm{mL}^{-1}$. Cell counting was also performed as a check, 
and a number higher than $3.18 \times 10^{9}$ cells $\mathrm{mL}^{-1}$ for the stock suspension was measured, thus the lower cell density calculated from the initial weighed yeast was considered more reliable for cell density characterization. The yeast cell density used for the reported tests is in accordance, or higher than, the generally accepted required dose of probiotics having health benefits $\left(10^{6}-10^{7}\right.$ cells/ mL[44]). For the G:CS blend crosslinking was performed using a solution of sodium hexametaphosphate, SHMP (Fisher Scientific, UK) in water.

Polymer Eudragit S100 (Evonik Industries, Germany) was used for coating the microparticles: Eudragit S100 was dissolved in a solution of ethanol: acetone (4:1) (Fisher Scientific, UK) with zinc stearate (Sigma Aldrich, UK) added. The Eudragit solution was emulsified in 2 wt.\% paraffin oil (Sigma Aldrich, UK). For washing of the particles either 2 wt. \% polyethylene glycol sorbitan monolaurate (Tween 20) (Sigma Aldrich, UK) in water, or hexane (Sigma Aldrich, UK) was used. The released yeast cells viability was checked using yeast glucose $(\mathrm{D}(+)$-Glucose anhydrous, Fisher Scientific, UK) consumption with time, and using the LIVE/DEAD® Viability/Cytotoxicity Kit, for mammalian cells, Molecular Probes, Invitrogen (California, US). The glucose concentration was measured using a glucose analyzer (G5, Analox Instruments Ltd., UK). The densities of both continuous and dispersed phases were measured using a glass density bottle. The viscosity of the phases were measured with a Rheometer AR100-N (TA instrument, USA), at $40^{\circ} \mathrm{C}$, using a cone-plate configuration. The cone geometry was $6 \mathrm{~cm}$ in diameter, $0.59^{\circ}$ with a truncation of $27 \mu \mathrm{m}$. The equilibrium interfacial tensions existing at the W/O interface were measured using the Du Nouy ring method on a White Electric Instrument tensiometer (model DB2KS). All the physical measurements performed on the continuous and dispersed phase used are shown in Table 1.

\subsection{Dispersion Cell Membrane Emulsification}

The W/O emulsion was prepared using a flat disk metal membrane in a Dispersions Cell supplied by Micropore Technologies Ltd (Redcar, UK). Above the membrane a paddle blade impeller was driven by a DC power supply (INSTEK, model: PR3060). The rotation of the impeller (200-1500 RPM) generates a shear stress (1- $17 \mathrm{~Pa}$ ) for droplet detachment at the membrane surface. Wetting of the membrane with the dispersed phase (W) needs to be avoided, or the dispersed phase will spread over the membrane surface, so nickel membranes treated to be hydrophobic were used. The hydrophobicity of the membranes was obtained by a coating, either PTFE 
or FAS were used. Coated membranes were supplied by Micropore Technologies Ltd (Redcar, UK). Both membranes had $30 \mu \mathrm{m}$ pore diameter with $200 \mu \mathrm{m}$ pore spacing $(30 / 200 \mu \mathrm{m})$.

\subsection{Experimental procedure}

\subsubsection{W/O emulsion production}

In the Dispersion Cell the disk membrane is placed in the base, underneath a glass cylinder on which an impeller is mounted, see Fig.1. The continuous phase of the emulsion is poured into the glass cylinder submerging the impeller and the membrane surface. The dispersed phase was injected into the system using a syringe pump (World Precision Instrument Inc., AL-1000, UK) forcing it to permeate through the membrane pores. The dispersed phase injection rate was between 1 to $5 \mathrm{~mL} \mathrm{~min}^{-1}$ corresponding to a transmembrane flux between 70 and $350 \mathrm{~L} \mathrm{~h}^{-1} \mathrm{~m}^{-2}$. In order to increase the membrane hydrophobicity, the membrane was soaked at least 30 minutes in kerosene with no surfactant present. The glass cylinder was filled with just less than $100 \mathrm{~cm}^{3}$ of continuous phase, and the amount of dispersed phase injected was $10 \mathrm{~cm}^{3}$ (10 vol.\% concentration emulsion). The whole Dispersion Cell was placed in a water bath and the emulsification process run at $40^{\circ} \mathrm{C}$. When the emulsification was completed the pump and the stirrer were switched off and the produced emulsion was poured from the glass cylinder into a beaker (with stirring) and analyzed. The Dispersion Cell was subsequently disassembled and the membrane washed. The membrane washing procedure consisted of removing the kerosene by washing the membrane with running water and using soap. Afterwards, the membrane was soaked in soapy water and sonicated for a maximum of 30 seconds using an ultrasonic bath. The membrane was then rinsed with water and dried with compressed air. The sizes of the aqueous phase drops in kerosene and size distribution were determined using the software ImageJ on microphotographs of the emulsions, and at least 300 drops per sample were measured. The droplet size was reported as $D_{a v}$, mean average droplet diameter using the following formula:

$$
D_{a v}=\sum_{i=1}^{n} \frac{n_{i} d_{i}}{N}
$$

Where $d_{i}$ is the $\mathrm{i}^{\text {th }}$ diameter of the droplet, $n_{\mathrm{i}}$ is the number of drops in the size range and $N$ is the total number of the droplets counted. The uniformity of the emulsion is reported as a value of Coefficient of Variation \% (CV\%) calculated as follows: 


$$
C V=\frac{\sum_{i=1}^{n}\left(d_{i}-D_{a v}\right) / N}{D_{a v}} \times 100(\%)
$$

\subsubsection{Microparticle solidification}

To obtain solid microparticles, the liquid drops in emulsion were solidified using either a thermal gelation process, or ionic crosslinking using SHMP. For the dispersed phase composed by the blend of G:CS in a ratio of 5:2 (G:CS (5:2)) the emulsion was initially cooled with ice for 30 minutes to set the gelatin, subsequently $10 \mathrm{~mL}$ of a $10 \mathrm{wt} \%$ SHMP solution was gently dripped into the emulsion to crosslink the chitosan. The reaction occurred under continuous stirring for 3 hours. When pure gelatin ( $5 \mathrm{wt} . \%$ gelatin in water) was used as dispersed phase, the drop solidification was obtained by thermal gelation: cooling the emulsion using an ice bath, under continuous stirring for 4 hours. In both cases the obtained solid particles were washed using $2 \mathrm{wt} . \%$ Tween 20 in water to remove any remaining kerosene phase.

\subsubsection{Microparticle coating}

Coating was performed on gelatin particles using the oil in oil $\left(\mathrm{O}_{1} / \mathrm{O}_{2}\right)$ solvent evaporation method previously described by L. Zhang et al [16]. The polymeric coating solution $\left(\mathrm{O}_{1}\right)$ was prepared using $2 \mathrm{wt}$ \% Eudragit S100 dissolved in a solution of ethanol:acetone at a volume ratio of 4:1. To prevent microparticle aggregation during the subsequent coating process, $20 \mathrm{mg}$ of zinc stearate was added to the organic phase which acted as an anti-sticking agent. The zinc stearate was not completely soluble in the coating solution therefore, to minimize the zinc stearate particle diameter the coating mixture was homogenized using an homogenizer (IKA® T 10 ULTRATURRAX®, Germany) at maximum speed (30,000 RPM) for 3 min. $3 \mathrm{~mL}$ of gelatin microparticles suspension was added to $10 \mathrm{~mL}$ to the coating solution $\left(\mathrm{O}_{1}\right)$ and stirred for 2 minutes providing a uniform dispersion of the particles. Coating solution $\left(\mathrm{O}_{1}\right)$ containing the microparticles was gently poured in to $50 \mathrm{~mL}$ of $2 \mathrm{wt} . \%$ SPAN 80 in Paraffin $\left(\mathrm{O}_{2}\right)$. The $\mathrm{O}_{1} / \mathrm{O}_{2}$ emulsion was stirred using the Dispersion Cell impeller at 5V (corresponding to 800 RPM) for 4 hours. The process of solvent evaporation was checked every hour; samples of the $\mathrm{O}_{1} / \mathrm{O}_{2}$ emulsion were withdrawn and examined under the optical microscope. Reduction of the $\mathrm{O}_{1}$ droplet size was observed until complete solvent evaporation and Eudragit polymer deposition on the gelatin microparticles oc- 
curred. The coated microparticles were washed using hexane and dried at room temperature overnight.

\subsubsection{Yeast loaded microparticles - dissolution study}

Simulation of the gastro-intestinal transit conditions was obtained varying the $\mathrm{pH}$ of the dissolution medium over time: the acidic stomach fluid was reproduced using a pH 1.2 for 2 hours, afterwards a pH 7 (or $\mathrm{pH}$ 8) medium was used to mimic the intestinal-colon area for a maximum period of time of 3 hours (or up to complete particle dissolution)[18]. The dissolution medium was prepared from a phosphate buffer saline (PBS, Sigma Aldrich, UK) solution (pH 7), adjusting the $\mathrm{pH}$ with hydrochloric acid (Sigma Aldrich, UK), or sodium hydroxide (Sigma Aldrich, UK). An initial amount of $15 \mathrm{mg}$ of dried particles was added to $1 \mathrm{~mL}$ of dissolution medium at $\mathrm{pH} 1.2$ and shaken in an incubator at $37^{\circ} \mathrm{C}$ for 2 hours. After 2 hours in an acidic environment, the microparticles were observed under the microscope and subsequently collected from the acidic buffer and resuspended in $1 \mathrm{~mL}$ of $\mathrm{pH} 7$ buffer for maximum 3 hours with shaking. Again the microparticles were recovered and observed, then re-suspended in $\mathrm{pH} 8$ buffer. Microphotographs of the microparticles were taken at regular time intervals, until dissolution of the particles and complete cell release.

\subsubsection{Released yeast viability determination}

The viability of the released cells from the microparticles was tested using two methods: yeast glucose metabolism with time was measured, and dyeing the yeast cells using a Live/Dead fluorescent kit and observation under the fluorescent microscope. Once released from the microparticles, the yeast cells were centrifuged using an Eppendorf centrifuge at 1000 RPM for 2 minutes and re-suspended in a $6 \mathrm{mM}$ Glucose solution. The glucose solution with the yeast cells was subsequently placed in an orbital incubator (Sartorius Certomat BS-1, Sartorius AG, Germany) at $37^{\circ} \mathrm{C}$ and rotation speed of $150 \mathrm{RPM}$. At predetermined time intervals the cell suspension was centrifuged and $50 \mu 1$ of the glucose solution was withdrawn and analyzed for glucose concentration. Fluorescent probes were also used to determine the fraction of live/dead cells. Component A of the LIVE/DEAD ® Viability/Cytotoxicity Kit (Calcein AM) is retained in living cells giving a bright green fluorescence if excited using a fluorescein optical filter (485 $\pm 10 \mathrm{~nm})$. In dead cells component B (Ethidium homodimer-1) enters in cells with a damaged membrane and binds 
to the nucleic acid giving a bright red fluorescence when excited under a typical rhodamine optical filter $(530 \pm 12.5 \mathrm{~nm})$. The samples were prepared by addition of the two probes to the yeast suspension and incubation at $37^{\circ} \mathrm{C}$ for 40 minutes, prior to the observation with the epifluorescence microscope Nikon Ti Eclipse.

\section{Results and discussion}

\subsection{Influence of emulsification process parameters and cells presence on droplet size and uniformity}

Variation of droplet average diameter and uniformity with dispersed phase flux and shear stress was investigated using a dispersed phase containing either $5 \mathrm{wt} . \%$ gelatin mixed with 2 wt.\% chitosan, or $5 \mathrm{wt} . \%$ of pure gelatin in water. The continuous phase for all the experiments was 2 wt.\% SPAN 80 in kerosene. Emulsions were produced with, or without, addition of yeast cells to the dispersed phase and the results are shown in Fig. 2. Initially a dispersed phase flux of $350 \mathrm{~L}$ $\mathrm{h}^{-1} \mathrm{~m}^{-2}$ was used and the stirrer rotation speed was changed from 2 to $9 \mathrm{~V}$ giving a shear stress from 1 to $17 \mathrm{~Pa}$. The corresponding average droplet diameter, $\mathrm{D}_{\mathrm{av}}$ is reported in Fig. 2(a), it is shown that $\mathrm{D}_{\mathrm{av}}$ decreases with increasing shear stress. This trend is in accordance with data reported previously [29,37,42]. Modifying the shear stress applied it was possible to produce droplets sized between $60 \mu \mathrm{m}$ to $340 \mu \mathrm{m}$ using the $30 \mu \mathrm{m}$ membrane. The corresponding CV\% (Fig. 2(b)) was in a range between 17 to 30\%. The same set of experiments were repeated adding yeast cells in the dispersed phase; for comparable values of shear stress and dispersed phase flux the mean droplet size and uniformity did not change significantly suggesting that the presence of the cells did not influence the emulsion characteristics. The dotted line within Fig. 2 (a) reports the theoretical values of droplet size calculated using the following equation[45]:

$$
D=\frac{\sqrt{18 \tau_{\max }{ }^{2} r_{p}^{2}+2 \sqrt{81 \tau_{\max }{ }^{4} r_{p}^{4}+4 r_{p}^{2} \tau_{\max }{ }^{2} \gamma^{2}}}}{3 \tau_{\max }}
$$

Equation (3) represents the model used for the calculation of the theoretical droplet diameter $(D)$ as a function of the shear stress applied $\left(\tau_{\max }\right)$, the membrane pore radius $\left(r_{p}\right)$ and the interfacial tension $(\gamma)$ existing between the phases. As demonstrated in another work[37] the shear stress is not uniform on the membrane surface, the maximum shear reachable is at radial distance $\left(r_{\text {trans }}\right)$ 
from the center of the membrane and the maximum shear is normally used in equation (3). The maximum shear is calculated as $\tau_{\max }=0.825 \mu_{c} \omega r_{\text {trans }} / \delta$ where $\mu_{c}$ represents the continuous phase viscosity, $\omega$ is the angular velocity and $\delta$ is the boundary layer thickness $\delta=\sqrt{\mu_{c} / \omega \rho_{c}}$. In Fig. 2 (a) the results obtained using a dispersed phase flux of $70 \mathrm{~L} \mathrm{~h}^{-1} \mathrm{~m}^{-2}$ were much closer to the theoretical values calculated using the model. The shear-capillary model does not include the dispersed phase flux as a parameter affecting the droplet size, it is the theoretical 'smallest' drop size formed at zero flux rate, therefore reducing the transmembrane flux the divergence between real and theoretical droplet size decreases. The literature does contain models that add a volume to the drops caused by the injection volume flow rate $(J)$ and the drop formation time $(t)$ :

$$
V=V_{o}+t J
$$

where $V_{\mathrm{o}}$ is the volume of the drop predicted by a force balance, e.g. equation (3), and $t J$ is the extra volume of the drop caused by operating at a high injection rate and the finite time required for droplet formation[46]. However, in order to apply equation (4) the drop formation time has to be assessed and this will depend on the fraction of pores that are actively generating drops, which is rarely a known value. Thus, for the purpose of illustrating the key parameters influencing the drop formation in the system studied here the simple force balance model, as represented by equation (3), is presented.

Fig 3 shows images of emulsions produced using the same dispersed phase flux $\left(350 \mathrm{~L} \mathrm{~h}^{-1} \mathrm{~m}^{-2}\right)$ and varying the shear stress. The dispersed phase was G:CS (5:2) and continuous phase was 2 wt.\% SPAN80 in kerosene. The $D_{\text {av }}$ reduced gradually with increasing shear stress from 1 to 17 $\mathrm{Pa}$ and the uniformity of the size distribution was comparable for the 4 samples reported. Size and emulsion uniformity were investigated as a function of the amount of yeast cells added to the dispersed phase. The initial yeast dispersion $\left(3.14 \times 10^{9}\right.$ cells $\left.\mathrm{mL}^{-1}\right)$ was prepared using dried yeast powder. For the preparation of the dispersed phase, a calculated volume of the initial yeast dispersion was added to the polymeric dispersed phase. The dispersed phase was stirred for few minutes at $40^{\circ} \mathrm{C}$ until uniform dispersion of the cells within the phase was reached. The dispersed phase containing the cells was subsequently injected into the emulsification apparatus. The amount of yeast dispersion injected was gradually increased up to $3.14 \times 10^{8}$ cells $\mathrm{mL}^{-1}$. During the emulsion production, the operating parameters were: dispersed phase flux $350 \mathrm{~L} \mathrm{~h}^{-1} \mathrm{~m}^{-2}$, shear 
stress 17 Pa. Fig. 4 (a) shows the mean droplet size as a function of the yeast concentration: it is possible to see that the amount of cells did not affect the size of the emulsion produced. Using these operating parameters, drops sized $\sim 66 \mu \mathrm{m}$ were obtained, a good uniformity was achieved with a CV between 19 and $23 \%$ as reported in Fig. 4 (b). A cell concentration of 3.14 x $10^{8}$ cells $\mathrm{mL}^{-1}$ was the maximum used in order to avoid membrane damage, formation of cell agglomerates was observed at higher yeast concentration. The agglomerates could potentially block the membrane. Images of the produced emulsions containing yeast cells are shown in Fig. 5; microphotographs were taken using a magnification of $20 \mathrm{X}$ and $40 \mathrm{X}$ objective lenses to show the cells trapped in the liquid drops. Uniform distribution of the cells within the drops was achieved; the cells did not agglomerate; shape and color were normal. Although the number of cells per drop was high (especially at $3.14 \times 10^{8}$ cells $\mathrm{mL}^{-1}$ ), no yeast cells were found in the continuous phase, suggesting that the cells were successfully trapped within the droplets. The passage of the cells through the membrane, i.e. no filtering effect, was checked by injecting the cell suspension with the highest cell density used $\left(14 \times 10^{8}\right.$ cells $\left.\mathrm{mL}^{-1}\right)$ through a FAS coated membrane. For this test the yeast suspension in aqueous phase was injected through the membrane in the absence of any organic phase. After $10 \mathrm{~mL}$ of the cell suspension passed through the membrane, i.e. the same volume used in the ME, the pump was switched off and the suspension passed through the membrane was recovered and observed under the microscope. To check no cells were filtered, and remained below the membrane, the membrane was turned upside down and the cell suspension injected again. This is termed 'back-flushed' in Fig. 6, which shows: (a) the cell suspension before the injection through the membrane; (b) the cell suspension injected through the membrane; and (c) the cell suspension using the membrane turned upside down and back-flushed. It is possible to observe that the number of cells for the three images does not appreciably change and it is reasonable to deduce that they have the same cell concentration. Similar tests were done at the lower cell concentrations used and identical results were found: no membrane fouling observed. Hence, the non-tortuous pore channel membrane used did not appear to retain any of the yeast cells at the cell densities used in this work, and, therefore, the encapsulation efficiency of the yeast cells will be $100 \%$.

\subsection{Effect of membrane coating on droplet size and uniformity}


The importance of membrane wettability was demonstrated by Nakashima et al.[47], who showed that membrane wetting by the dispersed phase should be avoided for successful production of monodispersed emulsions. Therefore, in the production of W/O emulsions, the membrane should be thoroughly wetted by the continuous oil phase, in order to minimize the spreading of the dispersed phase on the membrane. Hydrophobic membranes can be produced by a process of coating of a surface with different materials[48,49]. The PTFE coated nickel membrane used gave reasonably monodispersed emulsions Fig. 7 (a). Under the best operating conditions a $\mathrm{CV}$ of the $17 \%$ was achieved. However, a PTFE coated membrane requires a delicate washing procedure to avoid membrane coating damage: warm soapy water and an ultrasonic bath for a maximum of $30 \mathrm{~s}$ was used for the washing. The PTFE coated membrane had a thermally bonded polymer coating on the metal surface, which made recoating the membrane (to maintain its hydrophobicity with multiple use) troublesome. To overcome this disadvantage, a FAS coated membrane was also tested for the production of the W/O emulsion. The results obtained using the two membranes are compared in Fig. 7, where emulsions produced using a new PTFE and FAS coated membranes are shown. For both systems the dispersed phase flux was $350 \mathrm{~L} \mathrm{~h}^{-1-} \mathrm{m}^{-2}$, and the shear stress was $17 \mathrm{~Pa}$. The dispersed phase was composed by $5 \mathrm{wt} . \%$ gelatin in water, with a yeast concentration of $3.14 \times 10^{7}$ cells $\mathrm{mL}^{-1}$. The continuous phase was made of 2 wt.\% SPAN 80 in kerosene. Fig. 7 (a.1) shows the surface of PTFE coated membrane while Fig. 7 (b.1) the surface of the FAS coated membrane. Both used membranes had $30 \mu \mathrm{m}$ pore diameter, $200 \mu \mathrm{m}$ pore spacing. The emulsion produced with the PTFE coated membrane was characterized by an average droplet size of $62 \mu \mathrm{m}$ with a CV\% of $18 \%$. For the emulsion produced with the FAS coating the average droplet size measured was of $82 \mu \mathrm{m}$ while the calculated CV\% was $22 \%$. The drops produced using the FAS coated membranes were noticeably larger in size than the ones produced using the PTFE coated membrane, suggesting that the PTFE coated membrane has a greater degree of hydrophobicity than the FAS coated membrane, when new. However, the simplicity of FAS coating may make it more practical for membranes intended for multiple uses.

\subsection{Process of drop solidification: thermal gelation and ionic crosslinking.}

For the dispersed phase composed by G:CS (5:2) the solidification process consisted of two steps: initially the emulsion was placed in ice to decrease the temperature to approximatively 
$0^{\circ} \mathrm{C}$, this induced the hardening of gelatin. After 30 minutes in ice, $10 \mathrm{~mL}$ of $10 \mathrm{wt} . \%$ sodium hexametaphosphate solution was gently dripped in to the emulsion. The mixture was stirred for 4 hours to complete the solidification of the two polymers keeping the temperature at $0^{\circ} \mathrm{C}$. The addition of the phosphate salt induced a gelation of the chitosan present in the polymeric mixture; hexametaphosphate anions provide strong electrostatic interactions with the positively charged amino groups of chitosan, acting as a physical crosslinker[32]. The combination of thermal gelation and ionic crosslinking produced solid microparticles; no difference in size was observed between the liquid droplets and the solidified microparticles re-suspended in water. Once dried at room temperature, the microparticles formed a free flowing powder. The yeast cells were immobilized into the solid polymeric material. Gelatin microparticles were also produced (with no CS present), several concentrations of gelatin in water were tested (1 to 5 wt.\%). For the solidification of this formulation, thermal gelation in ice was exploited. It was seen that if gelatin concentration was below $5 \mathrm{wt} . \%$ the particles did not form, even after increasing the gelation time. The selected concentration for the production of the gelatin particles was, therefore, 5 wt.\%. Unlike the G:CS (5:2) particles, the pure gelatin particles did not survive the drying process, the particles collapsed forming clusters of polymer and losing their spherical shape. For that reason the gelatin particles were washed and directly re-suspended in water. The gelatin microparticles re-suspended in water showed an increase of average diameter when compared to the diameter of the drops in the kerosene phase. For gelatin drops sized $76 \pm 2 \mu \mathrm{m}$ on average, gelatin microparticles (re-suspended in water) had a diameter of $100 \pm 2 \mu \mathrm{m}$. This effect could be due to water absorption and swelling of the gelatin particles once re-suspended in water after the process of washing.

\subsection{Influence of the Eudragit coating on the physical proprieties of the gelatin microparticles}

To protect the particles form an acidic environment coating of the particles formed by Eudragit S100 was performed. The coating was not performed on the G:CS particles as they did not dissolve within the gastro-intestine timeframe; i.e. they did not need to be protected. The coating reaction occurred in 4 hours, the reaction was monitored by observation of the particles in the $\mathrm{O}_{1} / \mathrm{O}_{2}$ emulsion during the formation of the Eudragit shell. Fig. 8 (a) shows an uncoated gelatin particles suspended in water, an image of the early stage of the reaction ( $\mathrm{t}=0$ minutes) is shown in Fig. 8 (b): a liquid shell surrounding the gelatin drop surface composed by the organic phase 
containing the coating material dissolved is visible. With the evaporation of the solvent, the Eudragit polymer gradually formed a solid layer; visible in Fig. 8 (c). The reaction was stopped and considered complete once the $\mathrm{O}_{1}$ drops were almost invisible leaving the solid Eudragit polymer. The particles were washed and dried at room temperature, giving a white powder. A small sample of coated particles was re-suspended in water and observed under a microscope. Fig.8 (d) shows one of the coated particles re-suspended in water. Compared to the un-coated microparticles, the coated ones are smaller in size: the mean size of un-coated particles (in water) was $100 \pm 2 \mu \mathrm{m}$, and water wet coated microparticles were $70 \pm 2 \mu \mathrm{m}$ in diameter. The water is extracted from the particles by the $\mathrm{O}_{1}$ phase during the process of coating producing shrinkage. When re-suspended in water the coating layer prevents water absorption, thus swelling is reduced.

3.5 Un-coated and coated particles: dissolution $\mathrm{pH}$ and temperature dependence release of the yeast cells.

In-vitro release studies were performed on the particles to test the yeast release with time at different $\mathrm{pH}$ of the medium. All the experiments were carried out at $37^{\circ} \mathrm{C}$. Three formulations were used for this test and compared. Fig. 9 shows images of the particles at different $\mathrm{pH}$ and time intervals. The yeast encapsulated particles made of G:CS $(5: 2)$ did not show any cell release; this formulation was extremely resistant to the acidic environment ( $\mathrm{pH} 1.2)$ and to neutral ( $\mathrm{pH} 7$ ) conditions even after 5 days. The crosslinked matrix did not dissolve as shown in Fig. 9 (a). The trapped yeast cells were immobilized within the polymeric matrix and the formulation failed to release the cells. Behavior of the G:CS formulation at the tested $\mathrm{pH}$ can be explained by the formation of a strong ionically crosslinked polymeric matrix. A complex coacervation occurs between proteins and the polyanion [50] preventing the dissolution of the two polymers in the release medium. No further analyses were conducted on this formulation. Fig. 9 (b) shows the gelatin microparticles that were initially placed at $\mathrm{pH} 1.2$, to mimic the stomach conditions. Unlike the previous formulation, the pure gelatin particles released very rapidly; they did not resist the acidic environment and released their contents after 5 minutes. The test was also conducted at neutral $\mathrm{pH}(\mathrm{pH} 7)$, in this case the gelatin particles dissolved slower, after 15 minutes the yeast particles were swollen and almost invisible, but the encapsulated yeast was still retained inside the polymer. After a time of 30 minutes, the gelatin 
particles were completely dissolved and the content released in the surrounding medium. The pure gelatin microparticles did not meet the requirements for a gastro-resistant formulation: they did not protect the yeast cells from the acidic environment of the stomach for a period of at least 2 hours[18]. Therefore, the Edudragit S100 coating was added to the gelatin particles to preserve the gelatin polymer during the residence at $\mathrm{pH} \mathrm{1.2;} \mathrm{allowing} \mathrm{dissolution} \mathrm{of} \mathrm{the} \mathrm{particles} \mathrm{only} \mathrm{in} \mathrm{a}$ neutral, or basic, environment (pH between 7 and 8) typical of the intestinal-colonic area[17]. Eudragit coated microparticles were tested and the results are shown in Fig. 9 (c). In the images, background debris of the coating material is present. At pH 1.2, after two hours, the microparticles still encapsulate the yeast without alteration of their shape, or swelling. The coated microparticles were removed from the acidic medium and transferred to a neutral environment at $\mathrm{pH} 7$; no change was visible after 30 minutes, but a significant modification is noticeable after 2 hours: the coating gradually dissolve, for some particles a visible breaking of the Eudragit shell exposing the gelatin internal part is noticeable. At this stage, however, the cells were not released from the internal gelatin matrix. After 3 hours the microparticles were completely dissolved and the structure was no longer visible, the yeast cells were released and they are visible as small spots on the background of the image. In a basic environment the release was faster: it is possible to see that after 15 minutes at $\mathrm{pH} 8$ the external coating was almost dissolved, but the particle shape is still visible. In 30 minutes the microparticles released completely the content, some residual part of the particles is still visible. Although the yeast cells were already released, the complete dissolution of the residual polymer was observed after 1 hour. The Eudragit S100 methacrylic polymer is insoluble in acids, protecting the microparticles from dissolution in the stomach environment. However, the formed Eudragit S100 layer on the gelatin microparticles dissolves at $\mathrm{pH}$ above 7 , leaving the gelatin material exposed, and simple melting of the gelatin at $37^{\circ} \mathrm{C}$ produced the release of yeast cells in this medium.

\subsection{Yeast cell viability test}

\subsubsection{Glucose consumption analysis}

Yeast cells released from Eudragit S100 coated gelatin microparticles (Fig. 9 c) were collected and transferred into a $6 \mathrm{mM}$ glucose solution. The glucose concentration was measured at regular time intervals to check for yeast cell viability. Fig. 10 shows the reduction in glucose concentration measured with time, in terms of glucose consumed. The test was repeated for three 
samples. In the graph, the glucose consumed is reported as the percentage of the initial glucose amount consumed by the free yeast; calculated using the formula:

$$
\% \text { Glucose consumed }=\frac{\left(G l u_{i}-G l u_{n}\right) * 100}{G l u_{i}}
$$

Where $G l u_{i}$ is the initial glucose concentration $(6 \mathrm{mM}), G l u_{n}$ is the amount of glucose measured in the sample. The glucose was metabolized by the released cells with time reaching $90 \%$ consumption in 24 hours. This data shows that the encapsulation process did not damage the cells and that they were successfully protected from an acidic environment ( $\mathrm{pH}$ 1.2), equivalent to the conditions of the stomach, and after release when the conditions are no longer acidic the cells are still viable.

\subsubsection{Fluorescent analysis}

Two Fluorescent probes for cell dyeing were used to distinguish living cells from dead cells. Using an epifluorescence microscope the yeast cells encapsulated in the Eudragit coated particles (Fig. 9 c) and the yeast released from the particles (Fig. 9 c) were observed. In Fig. 11 (a) microparticles encapsulating the yeast is shown. From the image it is possible to see yeast cells coloured in green and a small number of cells coloured in red. The number of living cells is higher than the dead cells; however, the result may not be reliable as the cells are still held within a gelatin matrix. For this reason the yeast cells released, as described above, were also dyed and checked by fluorescence: Fig. 11 (b) shows these results. According to this analysis, the living cells are far greater in number compared to dead ones, showing that the encapsulation process was successful, the cells survived a period of time ( 2 hours) in acidic conditions and were successfully released (and viable) on returning the particles to a neutral aqueous environment. These conditions mimic what would be expected to occur during the passage of the encapsulated particles through the human gastric system. Thus successfully delivering living cells to the colon.

\section{Conclusions}

Dispersion Cell ME was used for the production of W/O emulsions with hydrophobic membranes of $30 \mu \mathrm{m}$ pore diameter and $200 \mu \mathrm{m}$ pore spacing. The aqueous dispersed phase composed of a mixture of gelatin and chitosan, or just gelatin with yeast cells, used as an 
example of encapsulating a living organism. The oil continuous phase used to inject the encapsulated cells in to was $2 \mathrm{wt} \%$ SPAN 80 in kerosene. The dispersed phase flux was from 70 to $350 \mathrm{~L} \mathrm{~h}^{-1} \mathrm{~m}^{-2}$ and the maximum shear stress at the membrane surface was between 1 to $17 \mathrm{~Pa}$. Using these operating parameters monodispersed, CV below $25 \%$ for most of the emulsions, were obtained with drops sized between 70 to $340 \mu \mathrm{m}$. Tests with and without cells showed that the emulsion drop size, and uniformity, was not affected by the addition of the cells in the disperse phase. Tests were performed up to a maximum yeast cell concentration in the encapsulated in the drops of $3.14 \times 10^{8}$ cells $\mathrm{mL}^{-1}$. The yeast cell encapsulation efficiency was $100 \%$, checked by ascertaining that the non-tortuous pore channel membrane used did not filter any yeast cells when operating under the flow rate and yeast cell concentration conditions used in the emulsification process, and by observation of no cells occurring in the organic continuous phase. The performance of hydrophobic membranes coated with PTFE and FAS fluorinated compounds was compared showing that the PTFE coated membrane gave smaller drops than the FAS coated membrane. From this result it is concluded that the PTFE coated membrane is characterized by a higher degree of hydrophobicity, but the coating method makes it less favourable for repeated use after cleaning. FAS coated membranes are promising for repeated production of W/O emulsions due to the simplicity to recoat the same membrane. The process of solid microparticle formation consisted of a thermal gelation and/or ionic crosslinking using sodium hexametaphosphate. Eudragit S100 coating was performed on gelatin microparticles encapsulating cells using the oil in oil solvent evaporation method. The dissolution of the yeast loaded particles was checked at different time intervals in acidic $(\mathrm{pH} 1.2)$, neutral $(\mathrm{pH} 7)$ and slightly basic ( $\mathrm{pH}$ 8) environments to mimic the transit conditions through the gastro-intestinal tract. The Eudragit coated particles did survive the acidic environment for 2 hours without dissolving, or releasing, the yeast cells. After surviving acidic conditions, dissolution of the particles occurred at $\mathrm{pH} 7$ within 3 hours, and within 1 hour at $\mathrm{pH} 8$, with subsequent yeast release. A targeted $\mathrm{pH}$ dependent release of cells in simulated intestine-colon conditions was achieved. The cell viability after the release was demonstrated by the ability of the yeast to metabolize up to $90 \%$ of glucose added to the growth medium in 24 hours. A confirmatory test was performed using a live/dead cell staining with two fluorescent probes which showed that living yeast cells predominated. Yeast cells were chosen as a proof of concept showing that ME is a promising method for cell encapsulation; the process can be applied to a variety of micro- 
organisms according to the cell type and specific requirements, notably cell density and flow rate, provided that the membrane structure is non-tortuous as this does not filter the yeast cells from the injected phase within the matrix of the membrane.

\section{Acknowledgments}

The authors wish to acknowledge the support and help received from Dr Mariana Petronela Hanga regarding the use of the LIVE/DEAD $®$ Viability/Cytotoxicity Kit and the epifluorescence microscope for the yeast viability determination.

Bibliography

[1] A. Murua, A. Portero, G. Orive, R.M. Hernández, M. de Castro, J.L. Pedraz, Cell microencapsulation technology: Towards clinical application, J. Control. Release. 132 (2008) 76-83.

[2] R. Nedovic, V., \& Willaert, Applications of cell immobilisation biotechnology, Vol.8 ed., Springer Science \& Business Media, 2006.

[3] V.F. Duvivier-Kali, A. Omer, R.J. Parent, J.J. O’Neil, G.C. Weir, Complete Protection of Islets Against Allorejection and Autoimmunity by a Simple Barium-Alginate Membrane, Diabetes. 50 (2001) 1698-1705.

[4] P. de Vos, M.M. Faas, B. Strand, R. Calafiore, Alginate-based microcapsules for immunoisolation of pancreatic islets, Biomaterials. 27 (2006) 5603-5617.

[5] H.-L. Ma, S.-C. Hung, S.-Y. Lin, Y.-L. Chen, W.-H. Lo, Chondrogenesis of human mesenchymal stem cells encapsulated in alginate beads., J. Biomed. Mater. Res. A. 64 (2003) 273-281.

[6] N. Wang, G. Adams, L. Buttery, F.H. Falcone, S. Stolnik, Alginate encapsulation technology supports embryonic stem cells differentiation into insulin-producing cells, J. Biotechnol. 144 (2009) 304-312.

[7] M. Yoshida, E. Mardriyati, D. Tenokuchi, Y. Uemura, Y. Kawano, Y. Hatate, Structural Control of Core / Shell Polystyrene Microcapsule- Immobilized Microbial Cells and Their Application to Polymeric Microbioreactors, J. Appl. Polym. Sci. 89 (2003) 1966-1975.

[8] S.H. Cheong, J.K. Park, B.S. Kim, H.N. Chang, Microencapsulation of Yeast-Cells in the Calcium Alginate Membrane, Biotechnol. Tech. 7 (1993) 879-884.

[9] M.C. Raymond, R.J. Neufeld, D. Poncelet, Encapsulation of brewers yeast in chitosan coated carrageenan microspheres by emulsification/thermal gelation., Artif. Cells, Blood Substitutes, Biotechnol. 32 (2004) 275-291.

[10] V. Nedovic, A. Kalusevic, V. Manojlovic, S. Levic, B. Bugarski, An overview of encapsulation technologies for food applications, Procedia Food Sci. 1 (2011) 1806-1815.

[11] M.C. Raymond, R.J. Neufeld, D. Poncelet, Encapsulation of Brewers Yeast in Chitosan Coated Carrageenan Microspheres by Emulsification/Thermal gelation, Artif. Cells, Blood 
Substitutes, Biotechnol. (2004).

[12] K.D. Green, I.S. Gill, J. a. Khan, E.N. Vulfson, Microencapsulation of yeast cells and their use as a biocatalyst in organic solvents, Biotechnol. Bioeng. 49 (1996) 535-543.

[13] A.K. Mandwal, C.K.M. Tripathi, P.D. Trivedi, A.K. Joshi, S.C. Agarwal, V. Bihari, Production of L -phenylacetyl carbinol by immobilized cells of Saccharomyces cerevisiae, (2004) 217-221.

[14] P.H.R. Keen, N.K.H. Slater, A.F. Routh, Encapsulation of yeast cells in colloidosomes., Langmuir. 28 (2012) 1169-74.

[15] S. Graff, S. Hussain, J.-C. Chaumeil, C. Charrueau, Increased intestinal delivery of viable Saccharomyces boulardii by encapsulation in microspheres., Pharm. Res. 25 (2008) 12906.

[16] L. Zhang, F. Cao, B. Ding, Q. Li, Y. Xi, G. Zhai, Eudragit® S100 coated calcium pectinate microspheres of curcumin for colon targeting., J. Microencapsul. 28 (2011) 65967.

[17] EUDRAGIT® product brochure, (2016).

http://eudragit.evonik.com/sites/lists/HN/Documents/evonik-brochure-eudragit-EN.pdf (accessed September 15, 2016).

[18] A. Paharia, A.K. Yadav, G. Rai, S.K. Jain, S.S. Pancholi, G.P. Agrawal, Eudragit-coated pectin microspheres of 5-fluorouracil for colon targeting., AAPS PharmSciTech. 8 (2007) 12.

[19] M. Hori, H. Onishi, Y. Machida, Evaluation of Eudragit-coated chitosan microparticles as an oral immune delivery system, Int. J. Pharm. 297 (2005) 223-234.

[20] S.-H. Song, Y.-H. Cho, J. Park, Microencapsulation of Lactobacillus casei YIT 9018 using a Microporous Glass Membrane Emulsification System, J. Food Sci. 68 (2003) 195-200.

[21] H. Shintaku, T. Kuwabara, S. Kawano, T. Suzuki, I. Kanno, H. Kotera, Micro cell encapsulation and its hydrogel-beads production using microfluidic device, Microsyst. Technol. 13 (2007) 951-958.

[22] N.T. Annan, A.D. Borza, L.T. Hansen, Encapsulation in alginate-coated gelatin microspheres improves survival of the probiotic Bifidobacterium adolescentis 15703T during exposure to simulated gastro-intestinal conditions, Food Res. Int. 41 (2008) 184193.

[23] P. de Vos, H.A. Lazarjani, D. Poncelet, M.M. Faas, Polymers in cell encapsulation from an enveloped cell perspective., Adv. Drug Deliv. Rev. 67-68 (2013) 15-34.

[24] C.L. Hyndman, A.F. Groboillot, D. Poncelet, C.P. Champagne, R.J. Neufeld, Microencapsulation of Lactococcus lactis within cross- linked gelatin membranes, J. Chem. Technol. Biotechnol. 56 (1993) 259-263.

[25] S. Schaffellner, V. Stadlbauer, P. Stiegler, O. Hauser, G. Halwachs, C. Lackner, et al., Porcine islet cells microencapsulated in sodium cellulose sulfate, Transplant. Proc. 37 (2005) 248-252.

[26] Y. Eun, A.S. Utada, M.F. Copeland, S. Takeuchi, D.B. Weibel, Encapsulating Bacteria in Agarose Microparticles Using Microfluidics for High-Throughput Cell Analysis and 
Isolation, (2011) 260-266.

[27] S.R. Bhatia, S.F. Khattak, S.C. Roberts, Polyelectrolytes for cell encapsulation, Curr. Opin. Colloid Interface Sci. 10 (2005) 45-51.

[28] W. Koh, A. Revzin, M. V Pishko, Poly ( ethylene glycol ) Hydrogel Microstructures Encapsulating Living Cells, Langmuir. 18 (2002) 2459-2462.

[29] S. Morelli, R.G. Holdich, M.M. Dragosavac, Chitosan and Poly (Vinyl Alcohol) microparticles produced by membrane emulsification for encapsulation and $\mathrm{pH}$ controlled release, Chem. Eng. J. 288 (2016) 451-460.

[30] M. George, T.E. Abraham, Polyionic hydrocolloids for the intestinal delivery of protein drugs: Alginate and chitosan - a review, J. Control. Release. 114 (2006) 1-14.

[31] X.. Shu, K.. Zhu, Controlled drug release properties of ionically cross-linked chitosan beads: the influence of anion structure, Int. J. Pharm. 233 (2002) 217-225.

[32] K.C. Gupta, F.H. Jabrail, Preparation and characterization of sodium hexameta phosphate cross-linked chitosan microspheres for controlled and sustained delivery of centchroman., Int. J. Biol. Macromol. 38 (2006) 272-83.

[33] Z. Peng, Z. Li, Y. Shen, F. Zhang, X. Peng, Fabrication of Gelatin/Chitosan Microspheres with Different Morphologies and Study on Biological Properties, Polym. Plast. Technol. Eng. 51 (2012) 739-743.

[34] A.A. Karim, R. Bhat, Fish gelatin: properties, challenges, and prospects as an alternative to mammalian gelatins, Food Hydrocoll. 23 (2009) 563-576.

[35] H. Nguyen-Ngoc, C. Tran-Minh, Sol-gel process for vegetal cell encapsulation, Mater. Sci. Eng. C. 27 (2007) 607-611.

[36] J.M. Rabanel, X. Banquy, H. Zouaoui, M. Mokhtar, P. Hildgen, Progress technology in microencapsulation methods for Cell therapy, Biotechnol. Prog. 25 (2009) 946-963.

[37] M.M. Dragosavac, M.N. Sovilj, S.R. Kosvintsev, R.G. Holdich, G.T. Vladisavljević, Controlled production of oil-in-water emulsions containing unrefined pumpkin seed oil using stirred cell membrane emulsification, J. Memb. Sci. 322 (2008) 178-188.

[38] S.M. Joscelyne, G. Trägårdh, Membrane emulsification - a literature review, J. Memb. Sci. 169 (2000) 107-117.

[39] E. Piacentini, E. Drioli, L. Giorno, Membrane emulsification technology: Twenty-five years of inventions and research through patent survey, J. Memb. Sci. 468 (2014) 410422.

[40] A. Imbrogno, E. Piacentini, E. Drioli, L. Giorno, Preparation of uniform polycaprolactone Microparticles by membrane emulsification/solvent diffusion process, J. Memb. Sci. 467 (2014) 262-268.

[41] E. Piacentini, E. Drioli, L. Giorno, Membrane emulsification technology: Twenty-five years of inventions and research through patent survey, J. Memb. Sci. (2014).

[42] M.M. Dragosavac, R.G. Holdich, G.T. Vladisavljević, M.N. Sovilj, Stirred cell membrane emulsification for multiple emulsions containing unrefined pumpkin seed oil with uniform droplet size, J. Memb. Sci. 392-393 (2012) 122-129. 
[43] M. a. Suárez, G. Gutiérrez, J. Coca, C. Pazos, Geometric parameters influencing production of $\mathrm{O} / \mathrm{W}$ emulsions using flat metallic membranes and scale-up, J. Memb. Sci. 430 (2013) 140-149.

[44] J. Burgain, C. Gaiani, M. Linder, J. Scher, Encapsulation of probiotic living cells: From laboratory scale to industrial applications, J. Food Eng. 104 (2011) 467-483.

[45] S.R. Kosvintsev, G. Gasparini, R.G. Holdich, I.W. Cumming, M.T. Stillwell, Liquid-Liquid Membrane Dispersion in a Stirred Cell with and without Controlled Shear, Ind. Eng. Chem. Res. 44 (2005) 9323-9330.

[46] M.A. Suárez, G. Gutiérrez, J. Coca, C. Pazos, Stirred tank membrane emulsification using flat metallic membranes: A dimensional analysis, Chem. Eng. Process. Process Intensif. 69 (2013) 31-43.

[47] T. Nakashima, M. Shimizu, M. Kukizaki, Membrane Emulsification by Microporous Glass, Key Eng. Mater. 61-62 (1992) 513-516.

[48] N. Yamazaki, H. Yuyama, M. Nagai, G.-H. Ma, S. Omi, A Comparison of Membrane Emulsification Obtained Using SPG (Shirasu Porous Glass) and PTFE [Poly(Tetrafluoroethylene)] Membranes, J. Dispers. Sci. Technol. 23 (2002) 279-292.

[49] G.T. Vladisavljević, R.A. Williams, Recent developments in manufacturing emulsions and particulate products using membranes., Adv. Colloid Interface Sci. 113 (2005) 1-20.

[50] B. Wang, B. Adhikari, C.J. Barrow, Optimisation of the microencapsulation of tuna oil in gelatin-sodium hexametaphosphate using complex coacervation, Food Chem. 158 (2014) 358-365. 


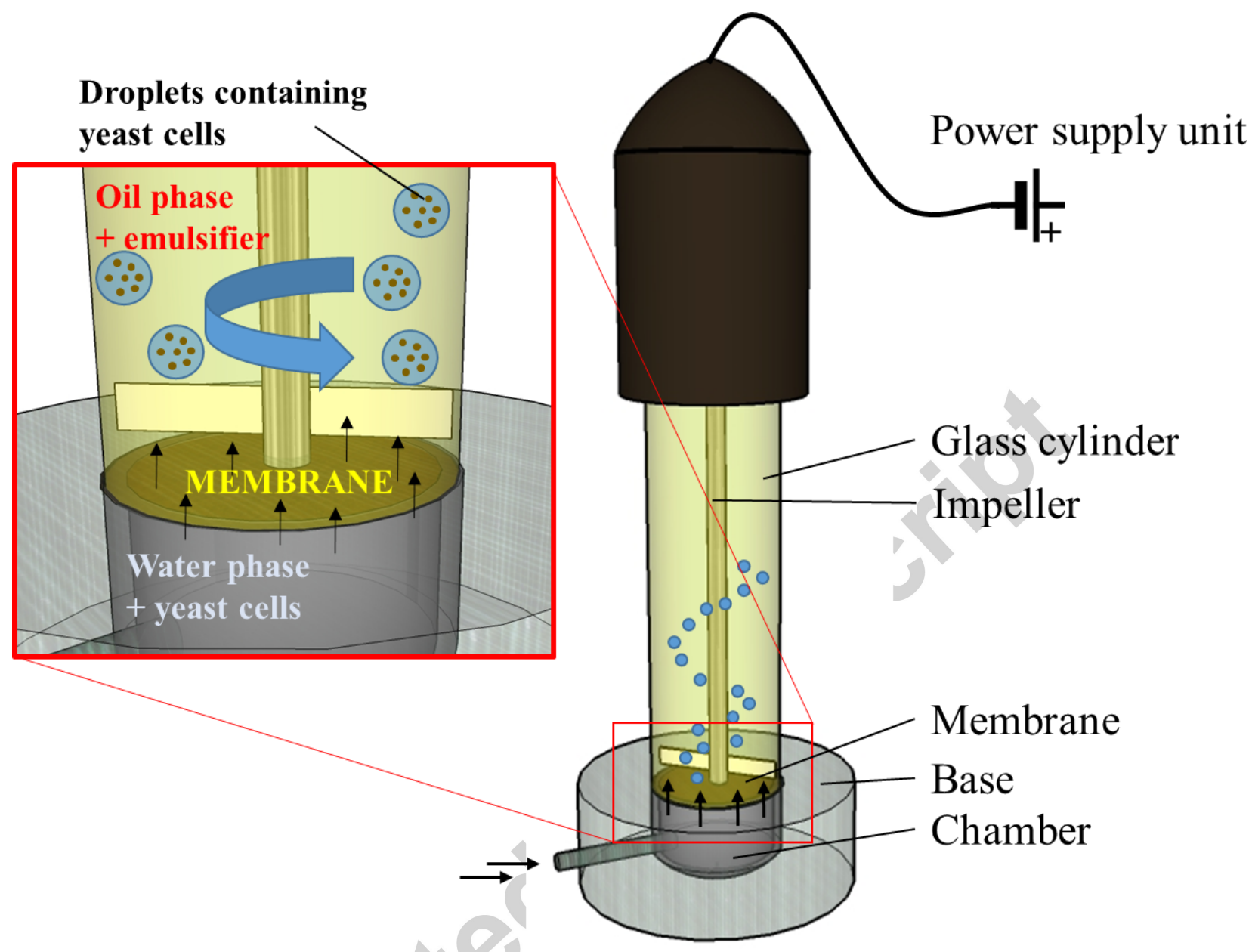

Fig. 1 Schematic representation of the Dispersion Cell device for Membrane Emulsification 


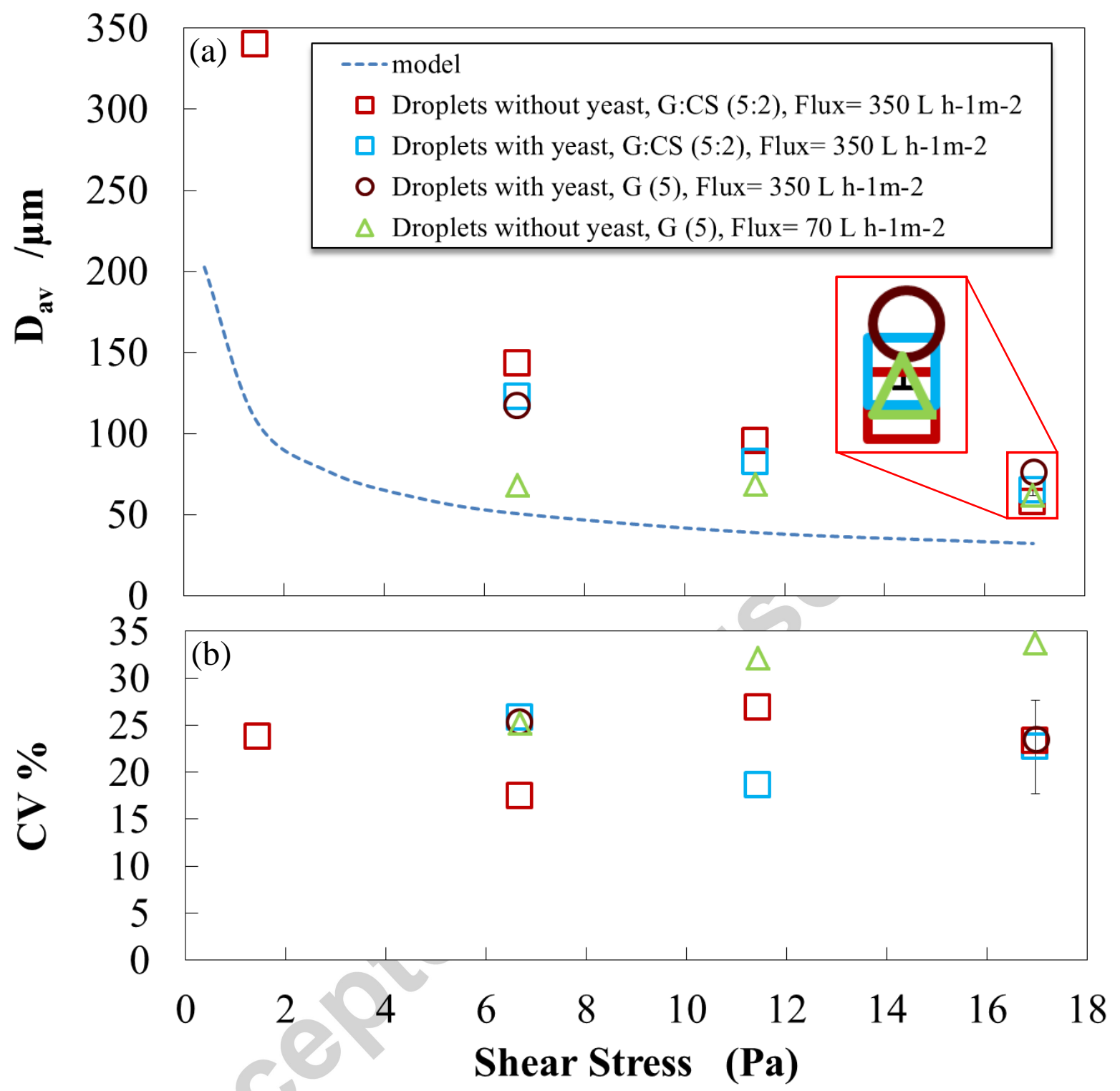

Fig.2 Influence of transmembrane flux and shear stress on size distribution. The hollow square marks represent experiments performed using a dispersed phase of G:CS (5:2) with and without yeast respectively. Hollow circle and triangle marks represent experiments performed using a dispersed phase of $\mathrm{G} 5 \mathrm{wt} . \%$ with and without yeast respectively. 


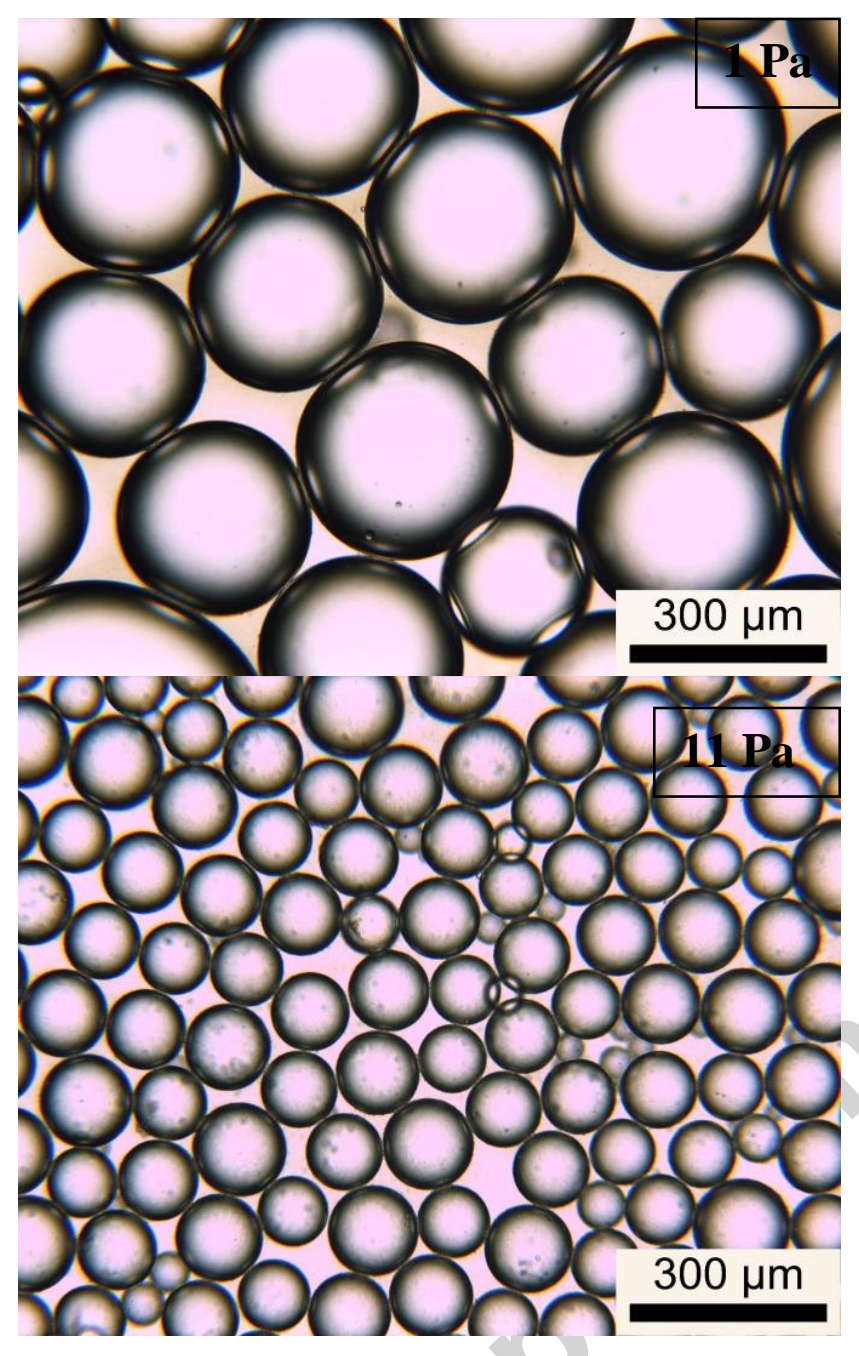

$7 \mathrm{~Pa}$

$17 \mathbf{P a}$ 

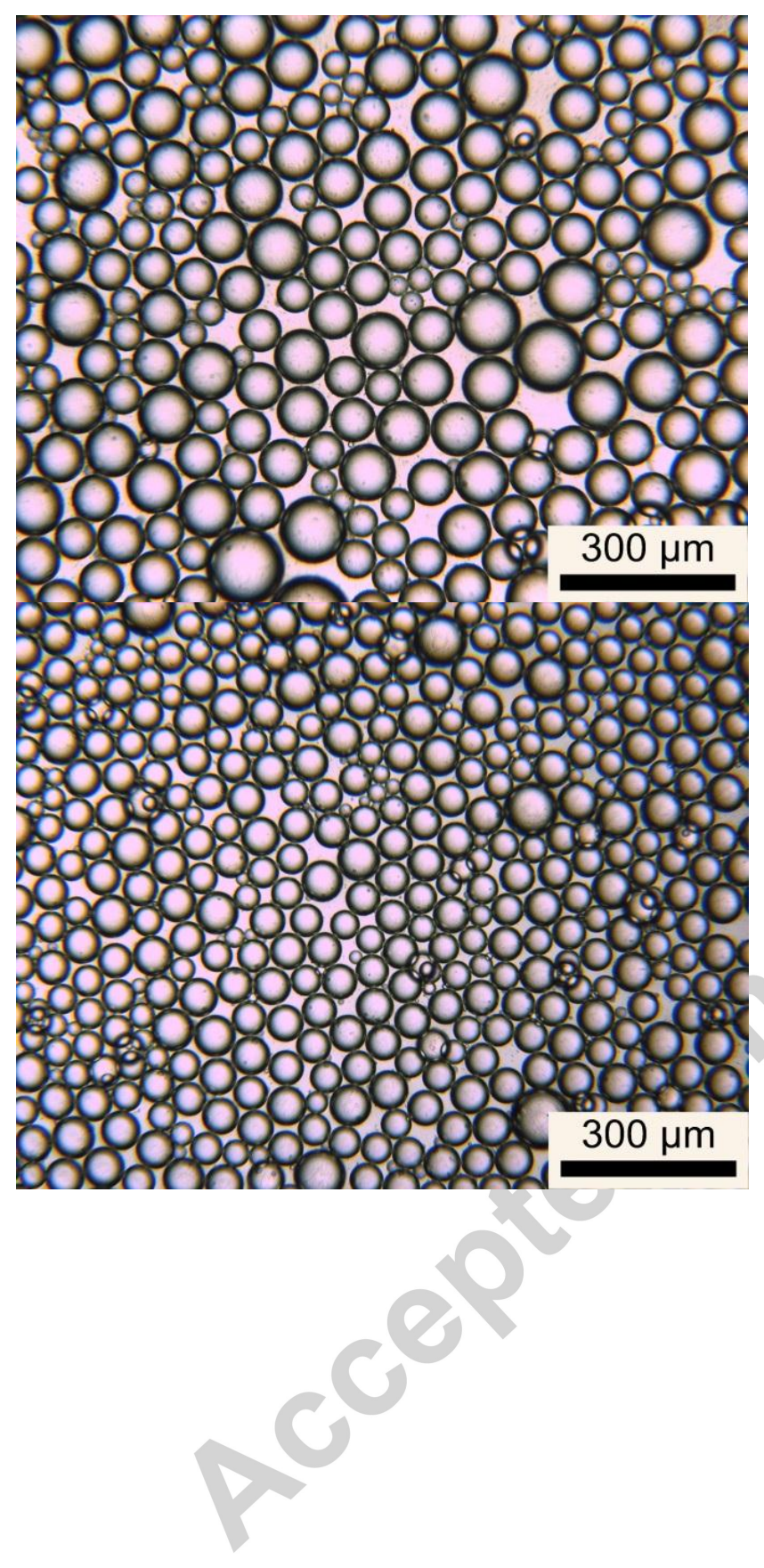
Fig. 3 Microphotographs of emulsions produced using $350 \mathrm{~L} \mathrm{~h}^{-1} \mathrm{~m}^{-2}$ as dispersed phase flux and shear stress from 1 to 17 Pa. Dispersed phase( G.G. $C S(5: 2)$, Continuous phase: 2 wt.\% SPAN 80 in kerosene.

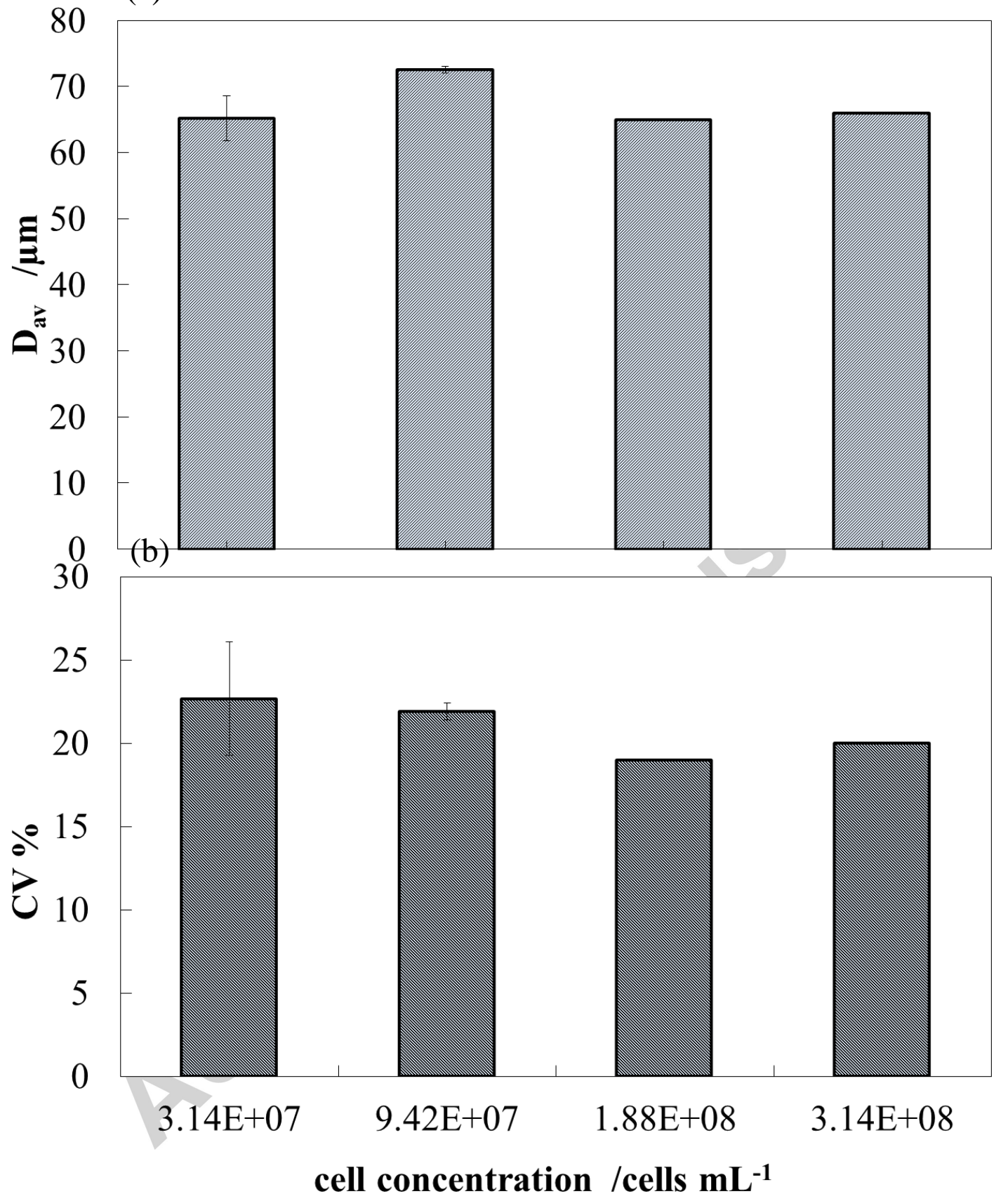

Fig.4 Average droplet size and CV at different cell concentrations. Dispersed phase: G 5 wt.\%, Continuous phase: 2 wt.\% SPAN 80 in kerosene. 

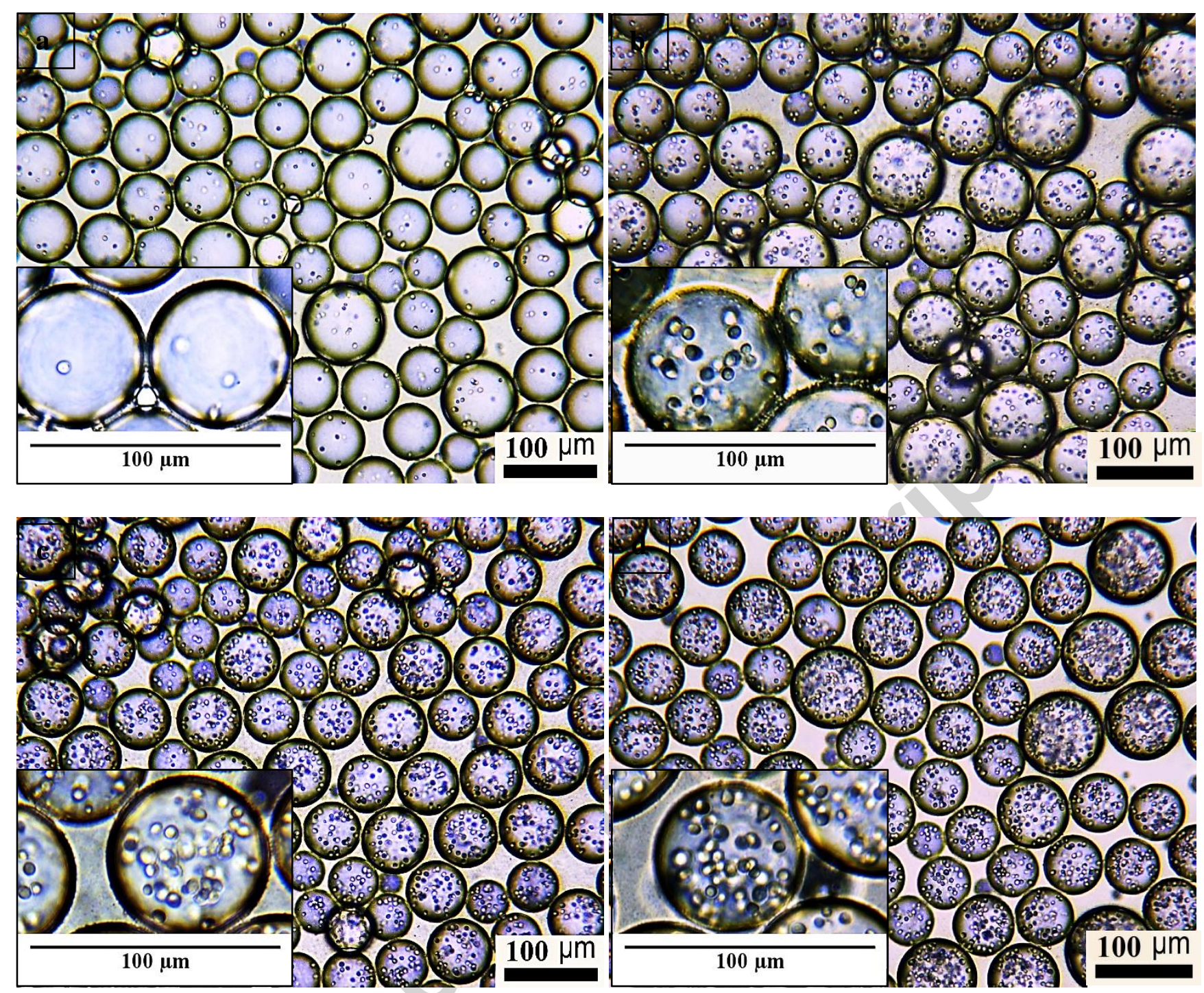

Fig. 5 Microphotographs of emulsions produced increasing the concentration of cells in the dispersed phase; $3.14 \times 10^{7}$ cells $\mathrm{mL}$

${ }^{1}$ (a), $9.42 \times 10^{7}$ cells $\mathrm{mL}^{-1}$ (b), $1.88 \times 10^{8}$ cells $\mathrm{mL}^{-1}$ (c), $3.14 \times 10^{8}$ cells/ $\mathrm{mL}(\mathrm{d})$. Dispersed phase: $\mathrm{G} 5$ wt.\%, Continuous phase: 2 wt.\% SPAN 80 in kerosene. Transmembrane flux $=350 \mathrm{~L} \mathrm{~h}^{-1} \mathrm{~m}^{-2}$, shear stress $=17 \mathrm{~Pa}$. 


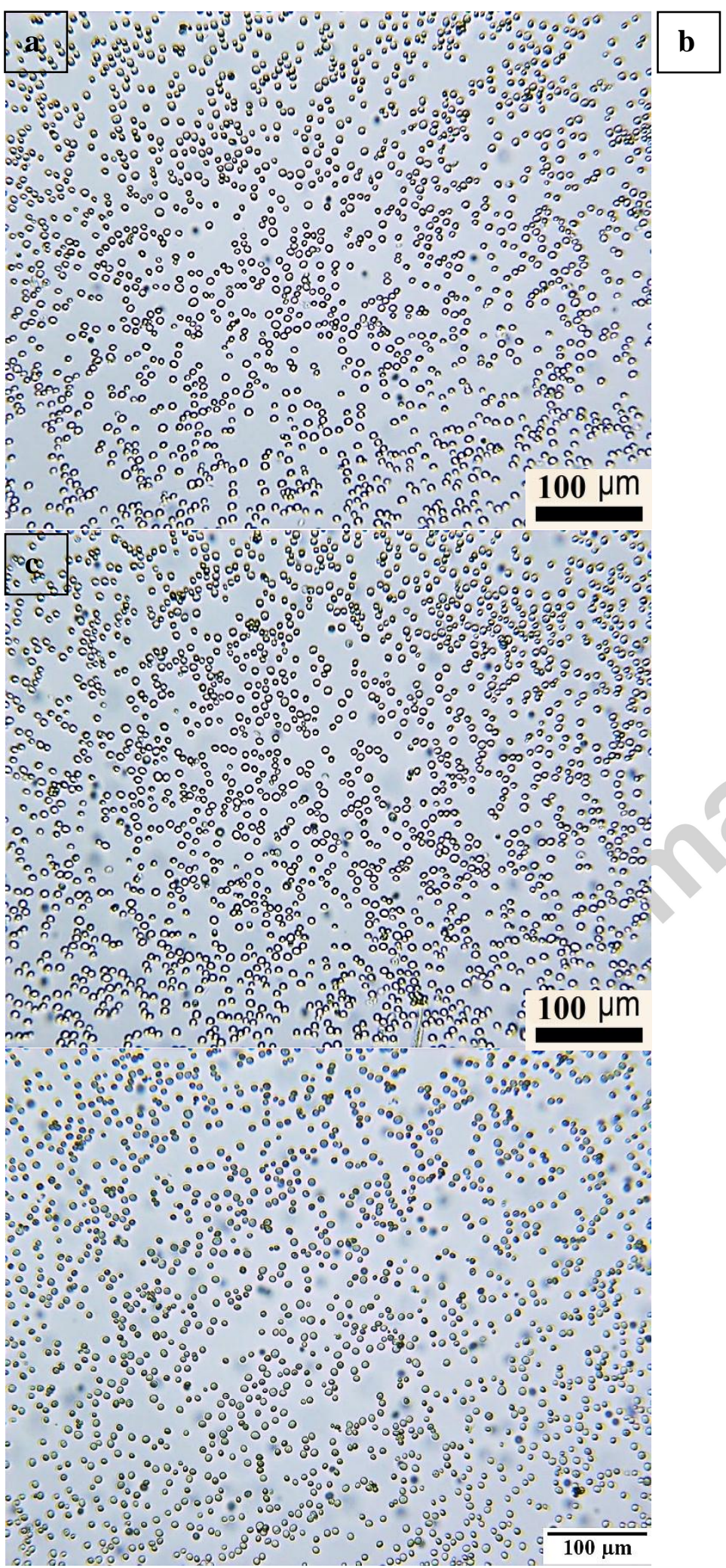

$100 \mu \mathrm{m}$

Fig. 6 Microphotograps of the cell suspension with the highest cell density $\left(3.14 \times 10^{8}\right.$ cells/ mL) used as dispersed phase; (a) starting cell suspension, (b) filtered cell suspension and (c) back flushed cell suspension. 

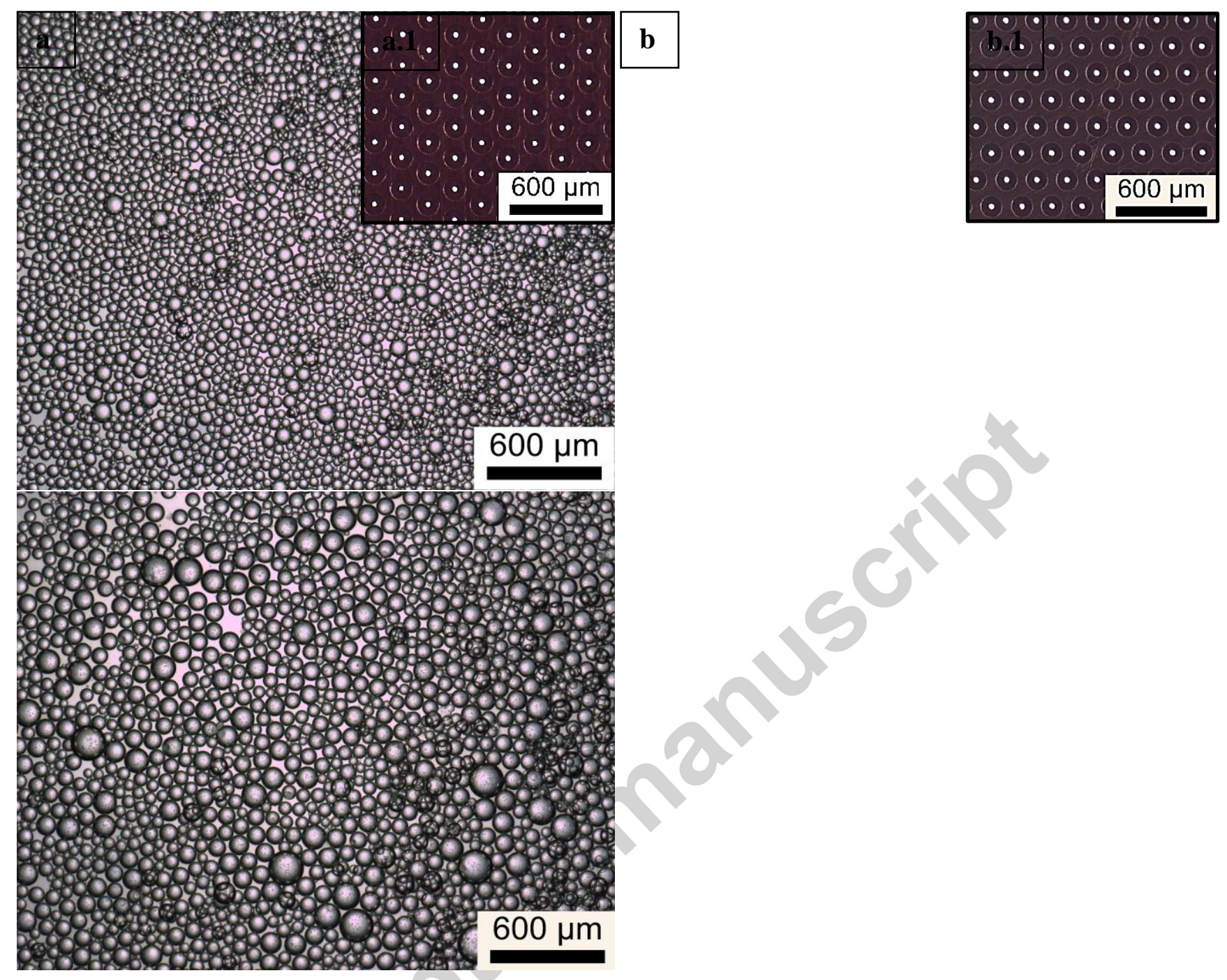

Fig. 7 (a) Emulsion produced using (a.1) standard nickel membrane PTFE coated 30/200 $\mu \mathrm{m}$, (b) emulsion produced using (b.1) standard nickel membrane FAS coated $30 / 200 \mu \mathrm{m}$ 

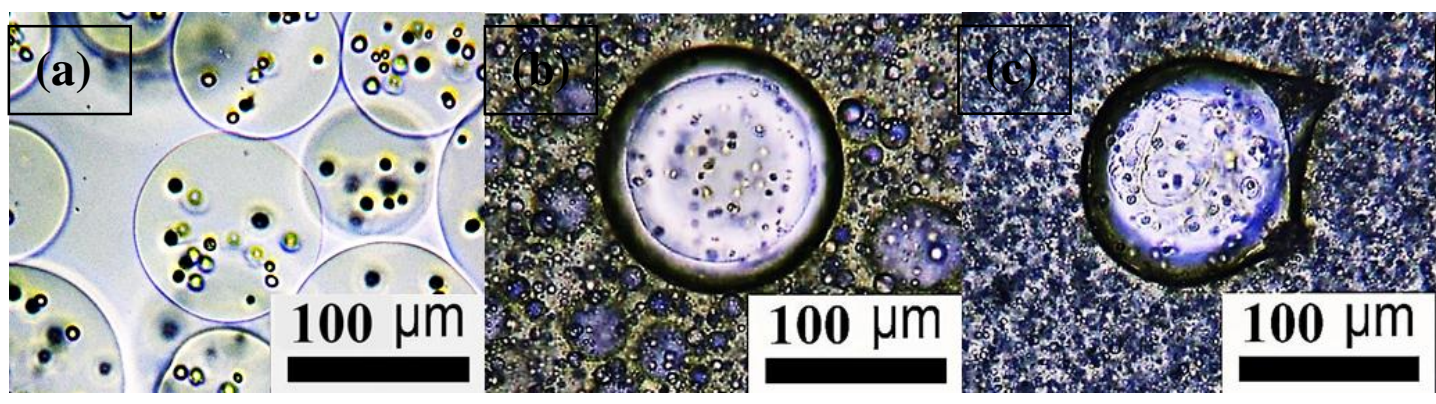

(d)

Fig. 8 (a) Uncoated microparticle in water (b) $\mathrm{O}_{1} / \mathrm{O}_{2}$ emulsion during the coating process after 0 minutes and (c) 4 hours, (d) microparticle re-suspended in water after washing in hexane and drying at room temperature. 
a)

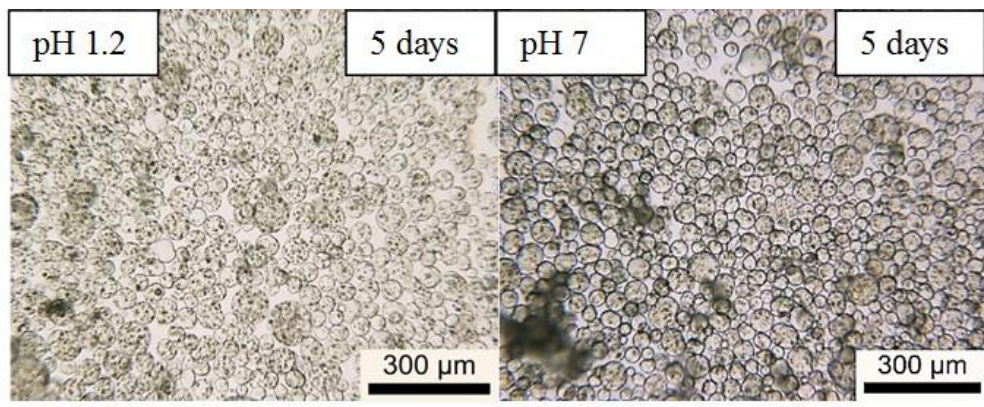

b)
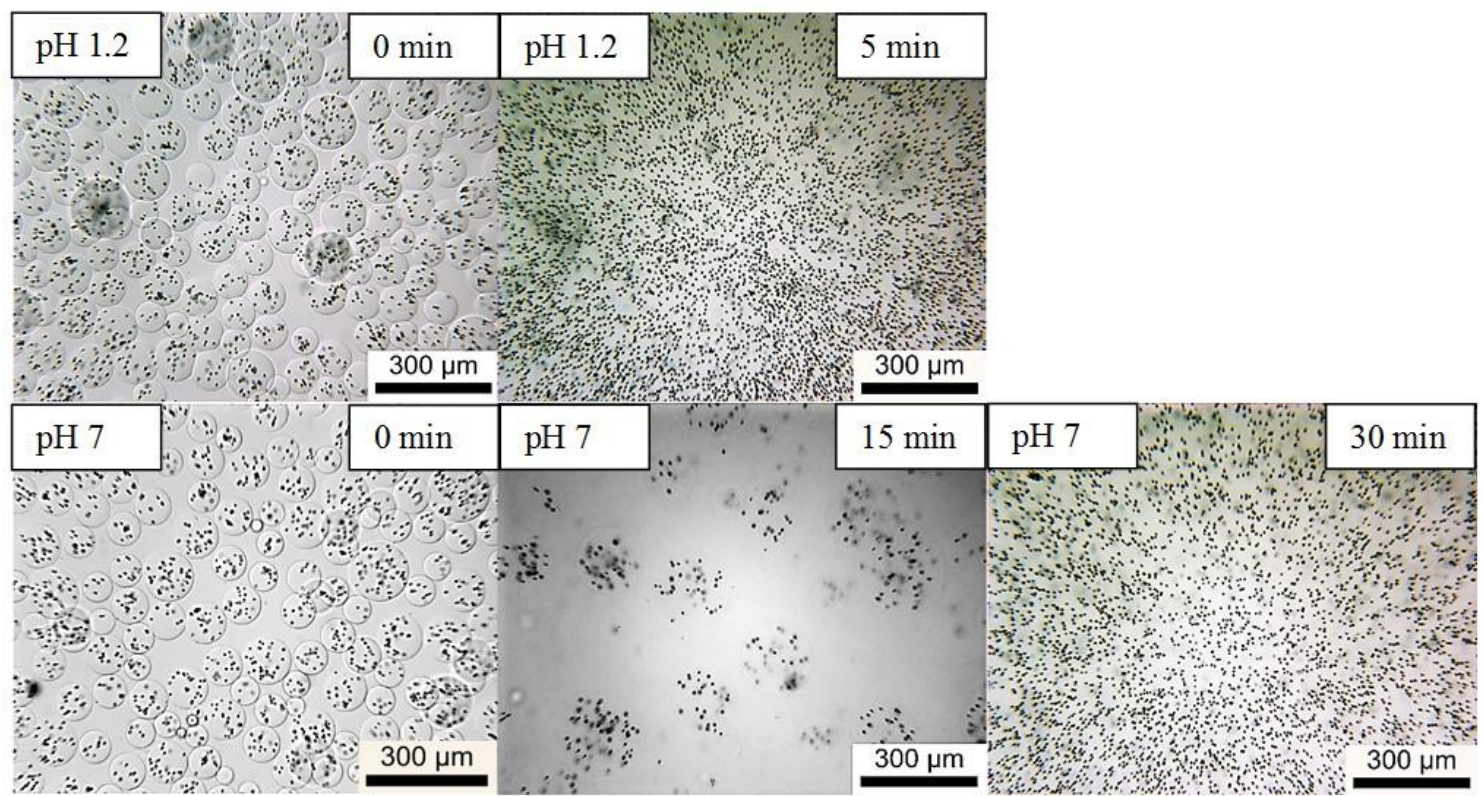

c)

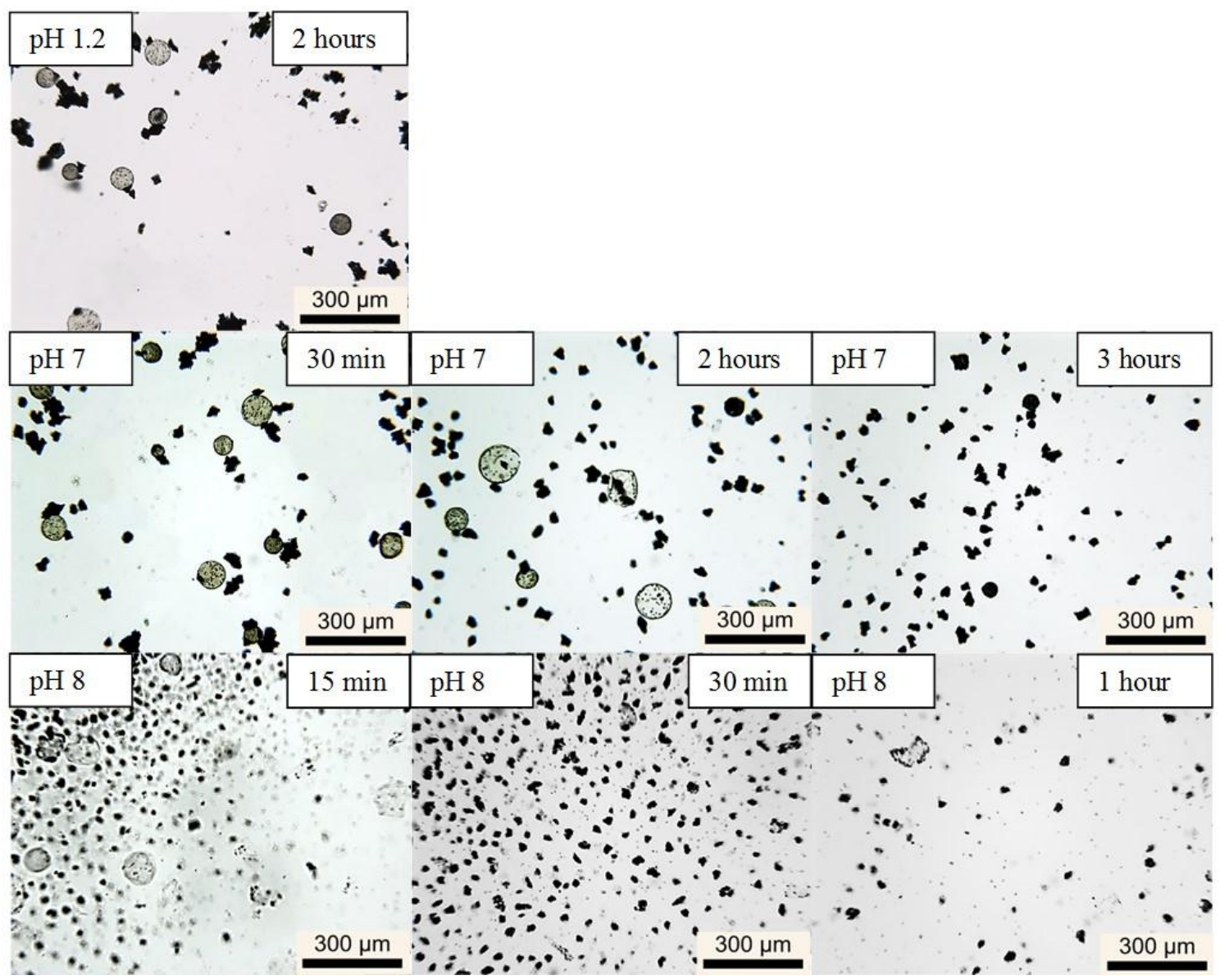


Fig. 9 Microparticles dissolution test with time at different pH; (a) G:CS (5:2) microparticles encapsulating yeast, (b) Un-coated G 5 wt.\% microparticles encapsulating yeast, (c) Eudragit S100 coated- G 5 wt.\% microparticles containing yeast. 


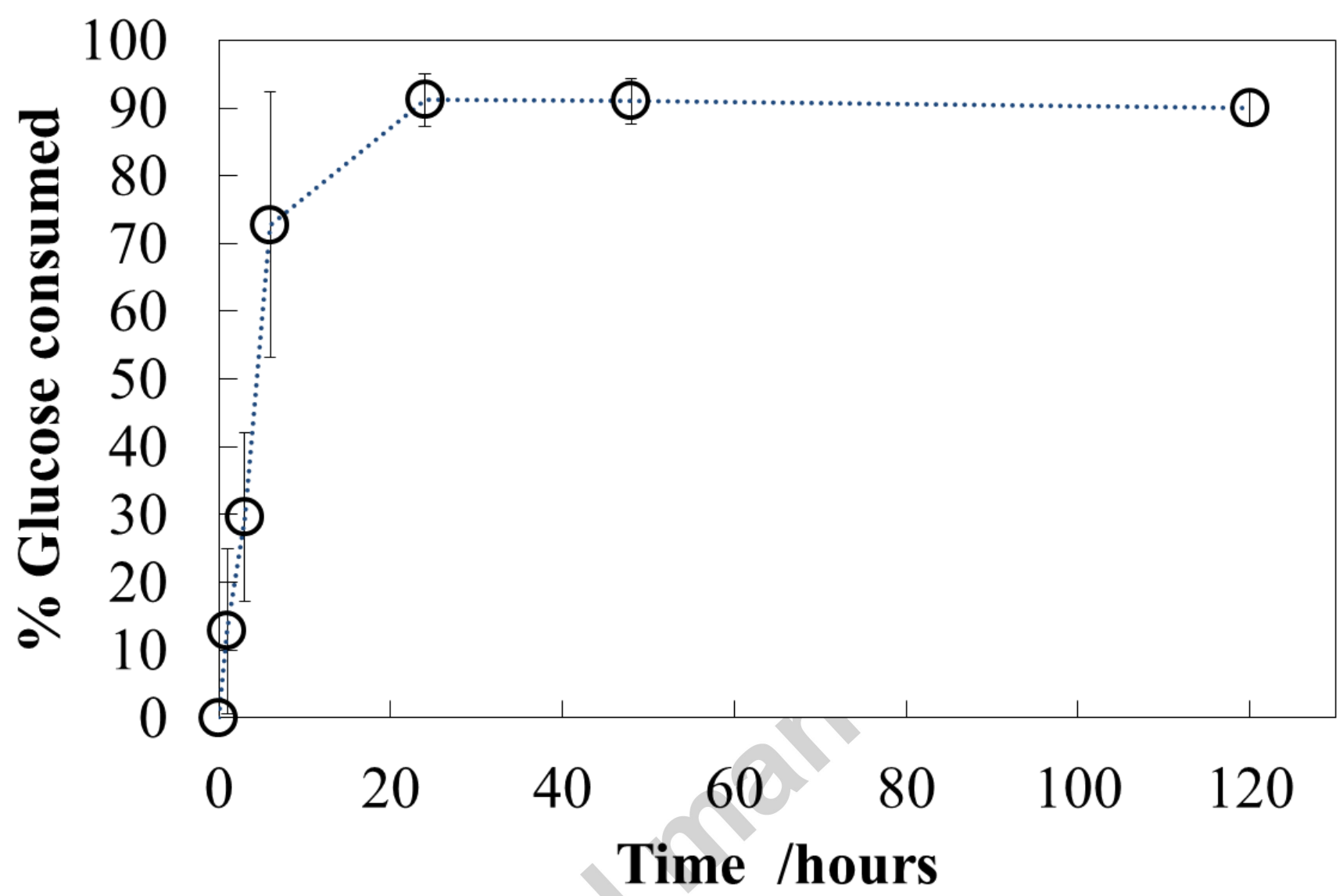

Fig.10 Released yeast glucose consumption with time as percentage of the initial amount of glucose consumed.
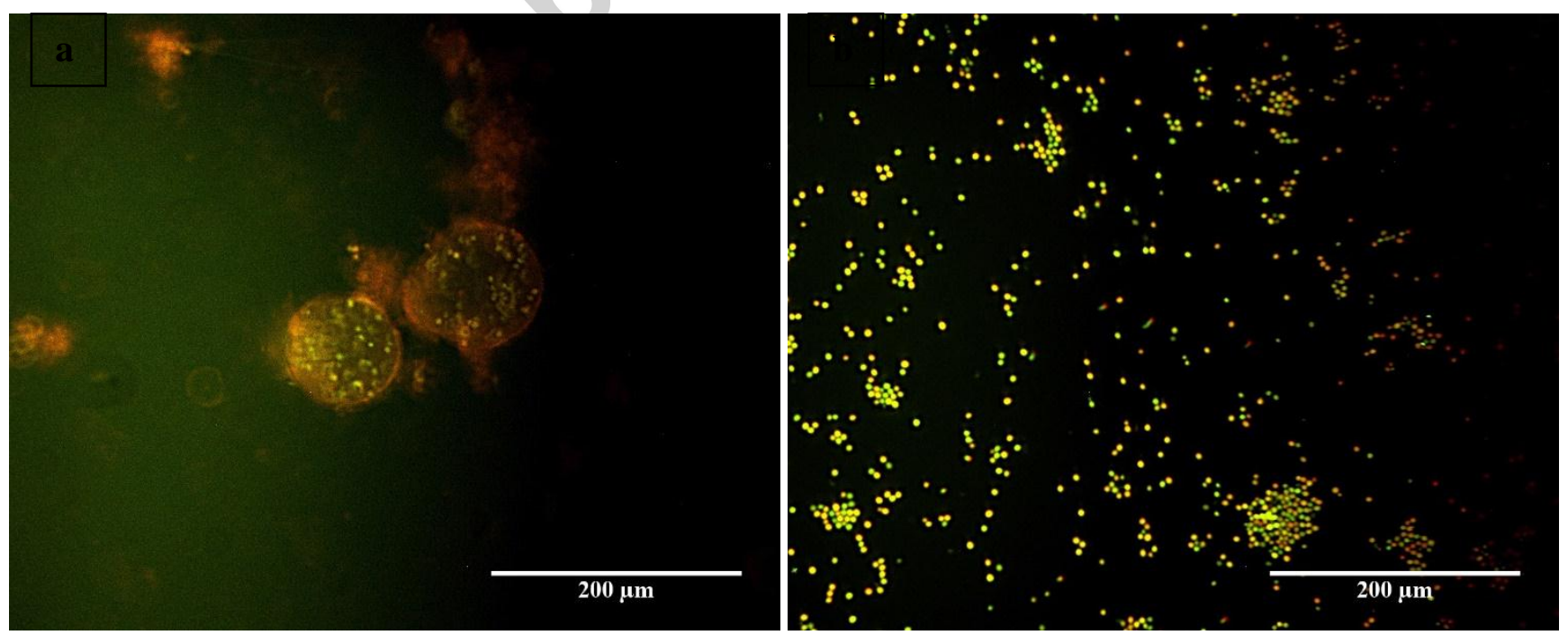

Fig. 11 Fluorescent microphotographs of (a) yeast cell still entrapped into the particles and (b) the released cell from the particles. Green-yellow colored cell are living, red-orange colored cell are dead. 
Table 1 Viscosities, densities and interfacial tensions measured for the continuous and dispersed phases used

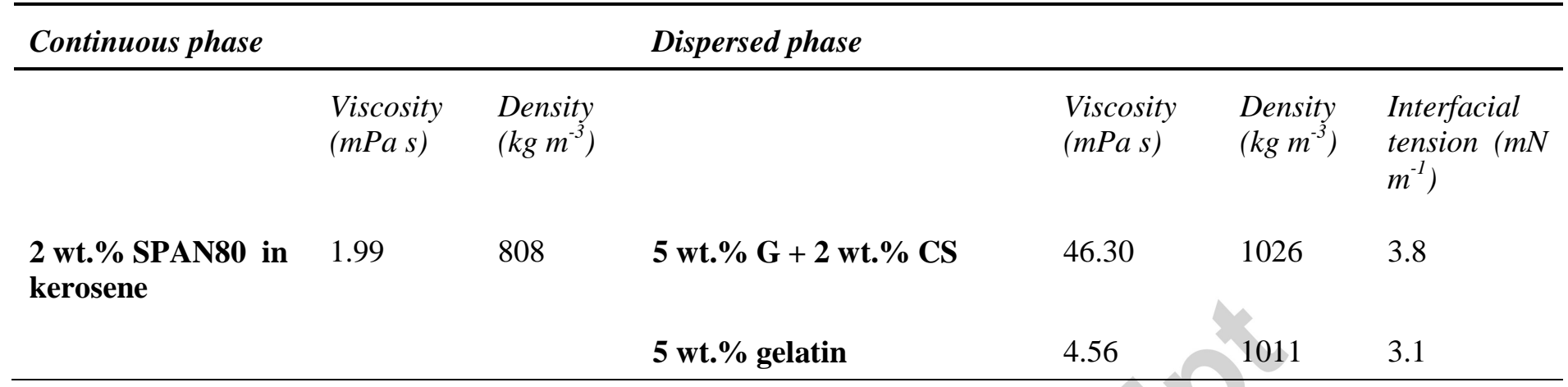

\section{Highlights}

- $\mathrm{W} / \mathrm{O}$ emulsion drops produced by membrane emulsification contained up to $3 \times 10^{8}$ cells/mL

- $\quad$ PTFE coated metal membrane, had high hydrophobicity and produced small drops.

- Gelatin and gelatin/chitosan microparticles were used to encapsulate yeast cells

- Eudragit S100 coated particles provided targeted release in neutral/ basic conditions

- Glucose consumption with time and live/dead staining confirmed cell viability 


\section{Graphical abstract}

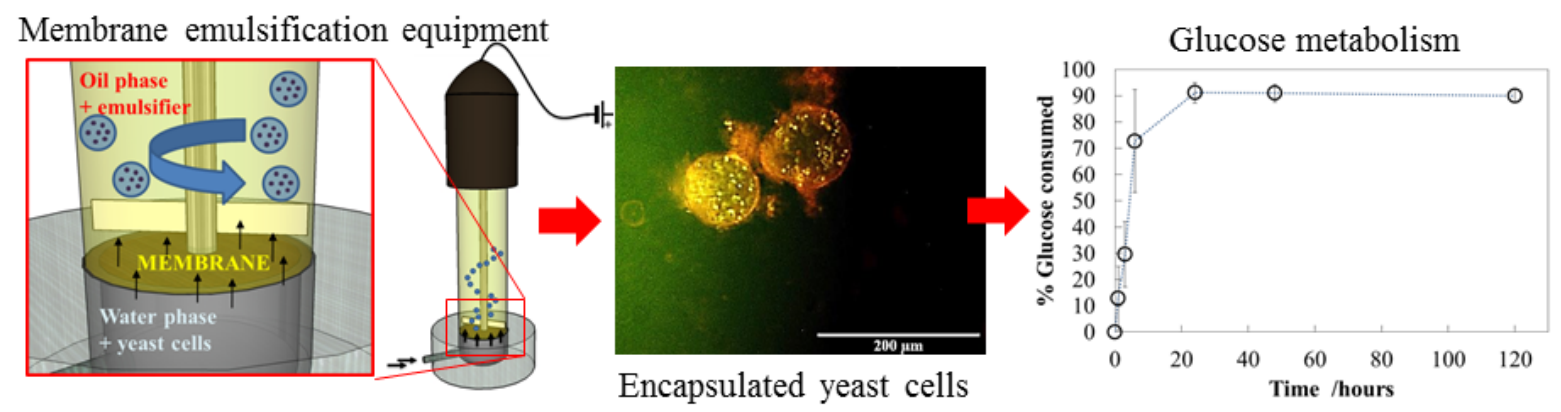

